\title{
Dionysiac Associations among the Dedicants of Hosios kai Dikaios Revisiting Recently Published Inscriptions from the Mihalıççık District in North-West Galatia
}

\author{
Altay COŞKUN*
}

\section{Introduction}

From 2014 to 2019, Hale Güney conducted epigraphic surveys in the Mihalıççı District and adjacent counties (Eskişehir Province) located between the northern bend of the Sangarios River (Sakarya Irmağı) and the Tembris / Tembrogios River (Porsuk Çayı). She has brought to light important new evidence especially for the rural cults and imperial estates in northwest Galatia during the 2nd and 3rd centuries. We have to be grateful for her swift publication of the materials on the Choria Considiana at Yukarı İğde Ağaç as well as on the cults of Hosios kai Dikaios, Zeus Sarnendenos, Zeus Akreinenos, Zeus Heptakomeiton, and Potamos. ${ }^{1}$ They add to the quickly growing body of scholarship on divine epithets and epicleses in Anatolia. ${ }^{2}$

The evidence for the divine pair Hosios kai Dikaiois deserves closer attention. Güney (2018a) has catalogued five inscriptions representing dedications to those gods. Four of them are her recent discoveries, whereas no. 5 offers an extended re-reading of a text previously published by J. G. C. Anderson and Stephen Mitchell. ${ }^{3}$ Some 176 inscriptions mentioning Hosios and / or Dikaiois had been accessible beforehand, most of all thanks to the exhaustive collections produced by Marijana Ricl. They include the recently published monuments by Tomas Lochmann and N. Eda Akyürek Şahin, though not yet the ones presented by Hale Güney, Emre Erten and Georg Petzl. If we maintain Ricl's practice to count in dedications to Theoi Dikaioi, the number is up to $185 .{ }^{4}$

\footnotetext{
* Prof. Dr. Altay Coşkun, University of Waterloo, Department of Classical Studies, ML 228, Waterloo ON, N2L 3G1 (acoskun@uwaterloo.ca; https://orcid.org/0000-0002-4672-6195).

My cordial thanks to Hale Güney for kindly sharing photos and bibliography, besides discussing various problems with me, and further to Phil Harland, Georg Petzl, N. Eda Akyürek Şahin and the anonymous reviewer for helpful critical feedback. Any remaining shortcomings are of course my own.

${ }^{1}$ Güney 2016 and 2018b on the Choria Considiana (cf. Mitchell 1988 = RECAM II 34); for the same and large estates such as of the Plancii, also see 2018c and 2018d; further 2018a on Hosios kai Dikaios; 2019a on Zeus Sarnendenos and Akreinenos; 2019b on Potamos; forthcoming on Zeus Heptakomeiton.

2 E.g., Chiai 2009, 85-98; Harland 2014, 143-149; Avram 2016a; Ricl 2017; Mitchell 2017; Piso 2018.

${ }^{3}$ Güney 2018a, nos. 1-4 and $5=$ Anderson 1899, no. 44, pp. 80 f. = Mitchell $1988=$ RECAM II 45.

${ }^{4}$ Ricl 1991; 1992a; 1992b; 1994, adding up to 118 inscriptions, updated 2008 (nos. 8, 9, 10, 19, 21, 36, 40 $=$ Akyürek Şahin 2004), though with confusing numbers (p. 563), with 58 further items (nos. 46-58 = Lochmann 2003). Güney 2018a (see below, part III); Erten 2018 (from Dorylaion); Petzl 2019b, $129=$ I.Sardis II 473. Theoi Dikaioi: I.Kibyra I 96 = Ricl 2008, no. 41; add two inscriptions found at Termessos by R. Fleischer

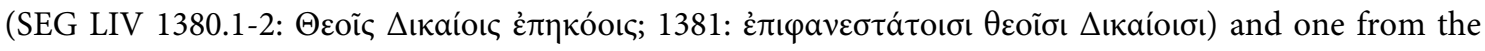
Antalya Museum of unknown provenance, published by Gökalp Özdil 2016, no. 10; The latest publication by N.E. Akyürek Şahin - H. Uzunoğlu (also in Gephyra 19) increase the number to nearly 200. The new evidence is not yet considered here, but will not change my conclusions.
} 
The new texts invite us to reflect on some aspects of the dedication formulae used in Phrygia, to gain some insights into the social texture of the adherents of the cult in northeast Phrygia, and eventually reconsider aspects of the cult organization or the lack thereof. As I shall try to argue, scholars have been too quick to understand Anatolian or Phrygian proper names ending on -enoi or -eanoi as ethnics denoting villagers and have thereby inadvertently downplayed the prevalence of associations (Greek thiasoi) that used similarly-construed names. ${ }^{5}$

I shall begin my investigation by surveying previous scholarship on the cult of Hosios kai Dikaios, as catalogued by Ricl, to provide the necessary background for our inquiry and classify elements of the dedication formulae (II). ${ }^{6}$ The main part will quote, discuss and revise the five (mostly) new inscriptions (III). In the conclusion, I shall try to redress the balance between village communities and cult associations among the dedicants to Hosios kai Dikaios and make some further inferences on how such groups were organized (IV).

\section{Dedications to Hosios kai Dikaios:}

\section{Some General Trends of the Phrygian Cult}

Most evidence for Hosios kai Dikaiois is from Phrygian territories in the Roman provinces of Asia and Galatia, with a particular concentration around the Türkmen Dağları between Eskişehir (Dorylaion) and Kütahya (Kotyaion). ${ }^{7}$ As Ricl has rightly noted, the Lydian material differs in presenting Hosios kai Dikaiois as a single deity, often represented as riding on a horse or an angellike divine messenger. In contrast, Phrygian Hosios kai Dikaiois seem to be two distinct gods, sometimes visually represented as twins holding scales and a staff (or measuring rod) respectively to symbolize their care for justice. They mostly appear jointly, at times in combination with other deities, especially Helios or Apollo, though in a few cases also individually. ${ }^{8}$ The epigraphic material further includes several instances in which the gender (Hosia kai Dikaia, Hosion kai Dikaion)

${ }^{5}$ For some orientation on the nature, function and organization of such associations in the Roman Empire, see Ascough - Harland - Kloppenborg 2012 as well as Harland 2013, though note that the focus of these works is more on urban associations.

${ }^{6}$ For a much more detailed analysis of the formulae as cultic speech acts, see Chiai 2008.

${ }^{7}$ See Ricl, esp. 1992a, 71-73; also 1991; 1992b; 1994; 2008; cf. Haspels 1971, vol. 1, 164, 192-204, 342-358 (nos. 115-154); Güney 2018a.

${ }^{8}$ Ricl 1991, 2-10 (nos. 1-18: Lydia); 10-16 (nos. 19-28: Phrygia Epiktetos); 17-19 (nos. 29-35: villages between Dorylaion and Nakoleia / Seyitgazi); 19-24 (nos. 36-46); 24-36 (nos. 47-78: sanctuary of Yaylaba Köyü); 36-39 (nos. 79-84: Aizanoi); 39-45 (nos. 85-98: rest of Phrygia and Galatia); 45-48 (nos. 99-106: other Anatolian territories); 48-49 (nos. 107-111: outside Asia Minor). On Lydian unity versus Phrygian duality, also see Ricl 1992a, esp. 73-75, 93-95, 97-101 (angel-like quality) and 2008, 563-564. Further see Känel 1990, nos. 1-6 and 7-12 ('Meßlatte'); Ricl 1992a, 79-84, 91-93; 2008, 564 f., 566 f.; Akyürek Şahin 2004, esp. 139-142; Erten - Sivas 2011, 187-190 on iconography and associated deities; also Erten 2018 on the horse-mounted Helios. For the concept of unity, add the one example from Macedonia, Ricl 2008, no.

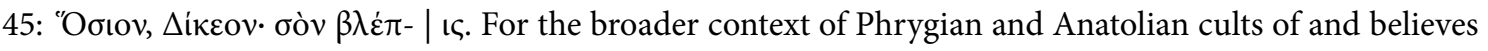
in divine concepts of justice, see Mitchell 1993, vol. 1, 187-195; Petzl 1994; 2019a. - For Theoi Dikaioi without Hosioi, see above, n. 4. Ricl 1991, no. 99 may have been adduced wrongly as an example of Dikaios alone, see the appendix below. 
and number (Hosioi kai Dikaioi) is varied. ${ }^{9}$ Such deviations do not obliterate the general trend of the cult that Ricl and others have described; at the same time, they reflect beliefs in the god(s) that were heterogeneous and malleable. We should therefore be cautioned against generalizing assumptions. ${ }^{10}$

The comparison with the distinctive evidence from Lydia further points to some different tendencies among those who made offerings to the god(s). Ricl realizes a higher proportion of priests among the dedicants in the south-west. ${ }^{11}$ One may add the observation that women, who rarely functioned as sole dedicants in Phrygia, seem to have had much more prominent roles in the cult activities among the Lydians. ${ }^{12}$ At any rate, in most of the cases catalogued by Ricl, dedicants can be identified as private individuals, whether they acted alone or with others, mostly relatives.

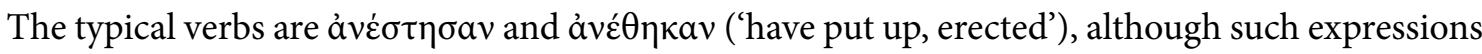

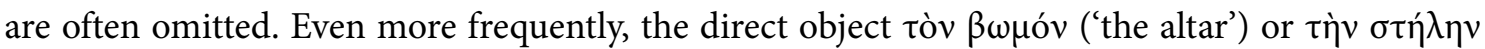
('the stele') remains implicit. Many cases end with a formulaic eủxn'v ('vow'): the accusative would

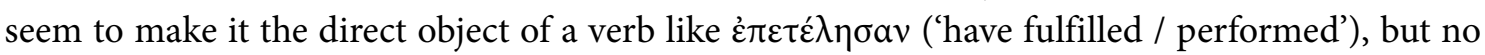
such case is attested in the evidence for Hosios kai Dikaios or some other representative material from Phrygia, Galatia and Lydia. Instead, some examples would rather be compatible with a phys-

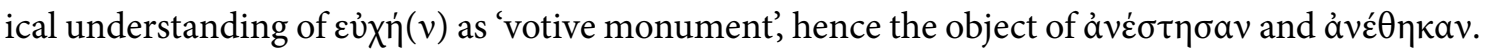
A few isolated instances from Sardis may warrant such a reading, but cases with two accusatives

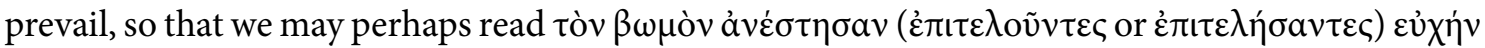

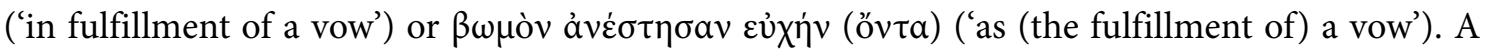
non-physical interpretation of $\varepsilon \dot{v} \chi \eta \dot{\eta}(v)$ is further encouraged by more elegant expressions such as

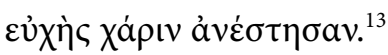

${ }^{9}$ See Ricl 1992a, 73-78 and 2008, 563-567 (reflections on the names and variants); cf. Akyürek Şahin 2004, 141; Erten - Sivas 2011, 190 f. (epigraphic survey).

${ }^{10}$ Pace Ricl 1992, 84 for 'une remarquable homogénéité iconographique', but see Känel 1990, vol. V.1, 542: 'Aus den Inschriften geht hervor, daß die Gottheit keinen fest umrissenen Charakter besaß, denn sie wurde nicht nur unterschiedlich bezeichnet, sondern auch mit anderen Gottheiten assoziiert.'

${ }^{11}$ See Ricl 2008, 565 f. on the dedicants, with reference to nos. 3 and 5 (cf. no. 42 from Kibyra = Corsten - Ricl 2012) for priests; no. 5 attests a priestess (three priestesses were previously attested in Phrygia: Ricl 1991, nos. 44, 92, 96; cf. 1992a, 89). The new evidence slightly conflicts with her previous observation (Ricl 1992a, $84 \mathrm{f}$.) that most of the Lydian dedicants were private people.

${ }^{12} \mathrm{Ricl} 2008,565$ f. generally comments on gender disparity. For the exceptional attestation of women, she references nos. 10, 32? from Phrygia, although women are documented much more often together with their husband (or whole family), for which Ricl cites nos. 12, 13, 15, 16, 18, 19, 22, 24, 33; add 40. But note that the five Lydian examples of Ricl's catalogue feature Elpis (no. 2), Meltine (no. 4), and the priestess Auge (no. 5) as sole dedicants, and further Gaiane after her husband, the priest Telesphoros (no. 3). Based on her first catalogue, Ricl 1992a, 86-87 observed full gender parity.

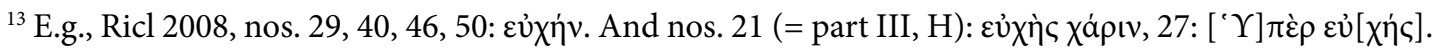
For further variation, see nos. 14, 22; Chiai 2009, 76, n. 64. I also compared all other dedications to Hosios and Dikaios (as above, n. 4 - the plural ev̉xác is discussed below, in part III, L and M), besides the indices of Mitchell 1988 = RECAM II and I.Ankara as well as Petzl, I.Sardis II and 2019a (Supplement to the Beicht-

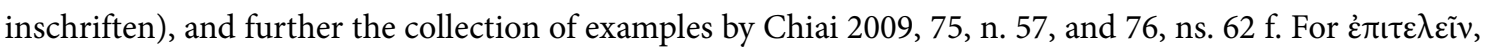

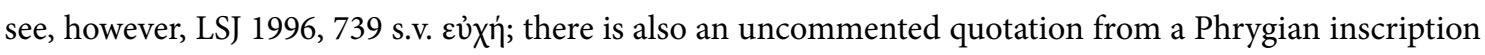


Multiple beneficiaries of the divine blessing could be named, whether or not in combination with a previous vow. Such composite formulae became particularly fashionable in 3rd-century Phrygia, with most of our evidence coming from Yaylababa Köyü in Kütahya Province. ${ }^{14}$ That the beneficiaries were the dedicants themselves can be taken for granted whenever the text is complete without anyone else being named. ${ }^{15}$ More often, however, the intended beneficiaries of the divine blessing are spelled out. This is regularly done with the formulae $\dot{v} \pi \grave{\varepsilon} \rho+$ genitive of person (1), iviè

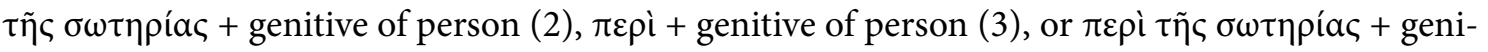
tive of person (4). Divine protection is thus mostly requested for the dedicant(s)' children (including foster children) (a), wife (b), husband (c), or other relative(s) or individual(s) close to the dedicant(s) (d). Often a formulaic expression such as 'for his own (kinsmen / family / people)' (e) is used instead of writing out names or relations. ${ }^{16}$ Only rarely, the group of beneficiaries is extended to a larger community, such as the whole village or 'fatherland' (f) of the dedicant(s). At all events, whenever sponsors of a dedication want to make sure that they, too, be included in the blessing,

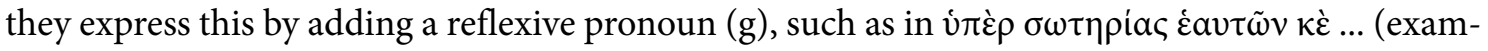
ple G).

There are of course further variations, such as the expansion of the dedicating subject instead of naming beneficiaries. ${ }^{17}$ Besides, some of the inscriptions are more verbose or even poetic; these instances tend to include similar elements, while using a less formulaic diction. They occasionally allude to the challenge in which the god(s) came to help and normally praise the divine supporters. ${ }^{18}$ I address only in passing that very few dedications to Hosios kai Dikaios are from funerary contexts; these are not my focus here. ${ }^{19}$

The following selection of more or less typical examples has been drawn from Ricl's 2008 catalogue. The bracketed number refers to the grammatical formula specifying the beneficiaries, with

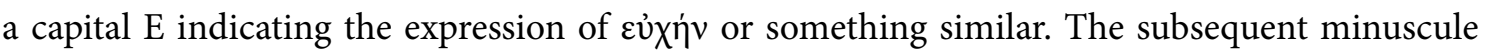
letters classify the beneficiaries of the dedication as explained above.

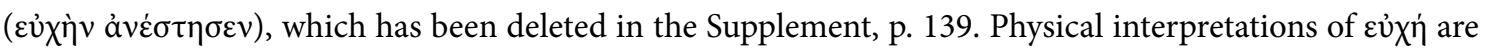

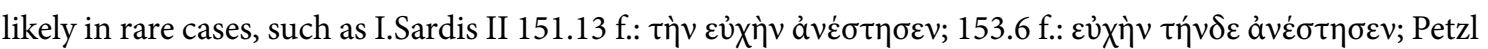
translates: 'hat ... das Ex-voto ... aufgestellt'.

${ }^{14}$ See Ricl 2008, nos. 7, 10, and the ones she quotes from Lochmann 2003 (Ricl 2008, nos. 48, 49, 51). But note one exception of unknown provenance, previously catalogued in İzmir (now lost), with an inverse

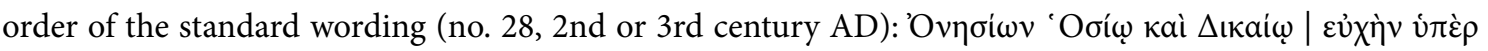
$\dot{\varepsilon}$ qutoũ | -----. Another exception is known from Afyon (no. 31, 3rd century AD). For more examples, see below, part III.

${ }^{15}$ Ricl 2008, e.g., nos. 8, 11 and further the examples H, I, J, K below.

${ }^{16}$ For a survey of the beneficiaries of cultic dedications in rural Asia Minor, see Chiai 2009, 70-72, also 77 for the notion of soteria.

${ }^{17}$ This can either be done by listing more nominatives (Ricl 2008, nos. 12, 13) or adding further dedicants of lesser status with the preposition $\mu \varepsilon \tau \dot{\alpha}+$ genitive or $\sigma u ́ v+$ dative (Ricl 2008, nos. 5, 16, 19).

${ }^{18}$ E.g., Ricl 2008, nos. 1, 22, 35.

${ }^{19}$ E.g., Ricl 1991, no. 88 from Phrygia and no. 103 from Mysia as well as Ricl 2008, no. 43 from Lycia (on

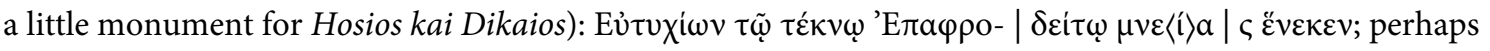
also no. 44 from Thessaly. 


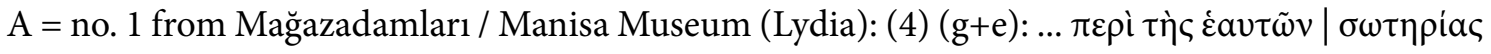

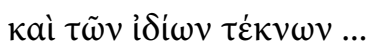

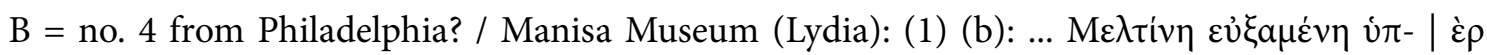

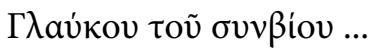

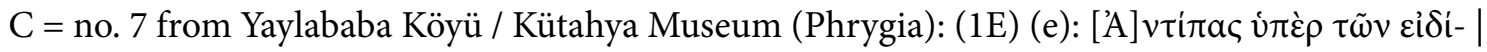

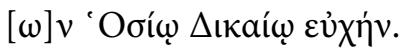

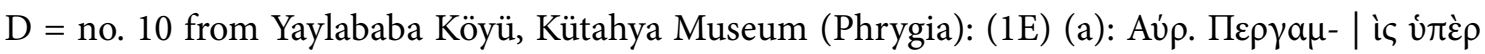

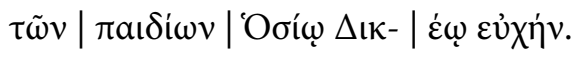

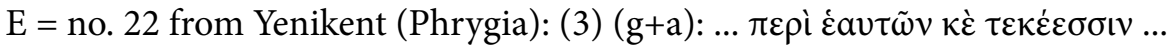

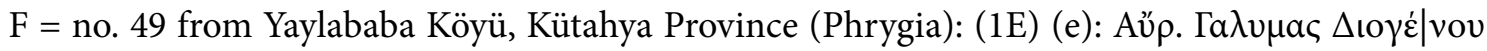

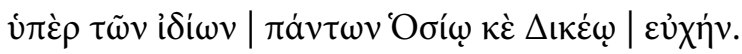

Ricl's 2008 catalogue includes only one example that specifies the larger community of the dedicant among the beneficiaries:

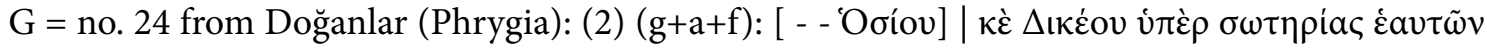

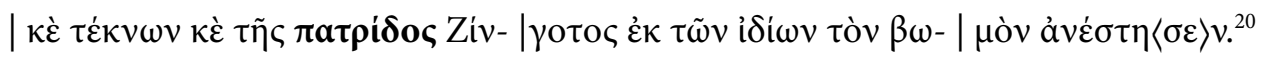

When village communities seek the benevolence of Hosios kai Dikaios, they are normally presented in the role of the dedicants. In her analytical survey, Ricl mentions only a single case, ${ }^{21}$ but her catalogue actually lists four further potential instances. Two of them are beyond doubt: they not only specify that the ethnonym pertains to a political community, but also avoid differentiating beneficiaries that were at any rate included among the villagers.

H = no. 21 from Muratlar Köyü near Kotyaion / Kütahya, 3rd century AD: (-E) (-): Oóí

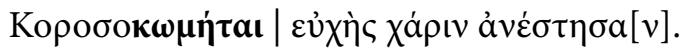

$\mathrm{I}=$ no. 30, probably from Lagina / Ilgin, now in the Konya Museum, 2nd-3rd century AD:

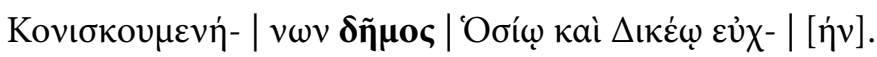

Less clear are the two remaining cases, which are generally understood as dedications by villagers as well. While it is compatible with this view that they refrain from singling out beneficiaries, too, I am uncertain about the first case but am sure that the second relates to a cult association:

$J=$ no. 37 from Ören Mevkii by Cuma Camii in Sansipahiler (Hadrianeia), dated to the 2nd cen-

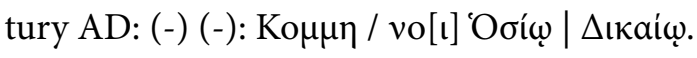

\footnotetext{
${ }^{20}$ The author of this inscription was apparently not fully literate: note the confusion of genitive and dative for the theonyms (which is frequent in Phrygian inscriptions though); the clumsy connection $\dot{\varepsilon} \alpha v \tau \tilde{\omega} v$

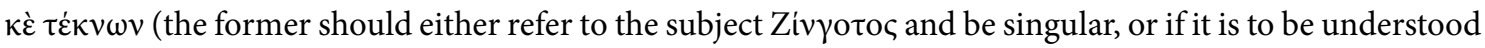
as $\tau \tilde{\omega} v i \delta i \omega v$, the singling out of the children is - at least grammatically, not of course emotionally - super-

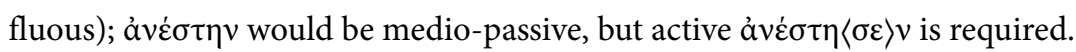

${ }^{21}$ Cf. Ricl 2008, 506, with no. 37 = J.
} 
$\mathrm{K}=$ no. 20 (first published by Erten - Sivas 2011 = SEG 63, 1225) ${ }^{22}$ from Akçakaya, near Avdan,

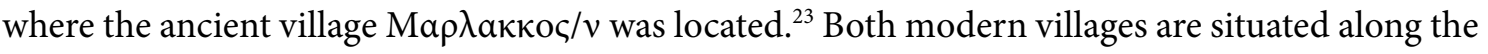
northern foothills of the Türkmen Dağları in-between the cities of Kotyaion / Kütahya, Dorylaion

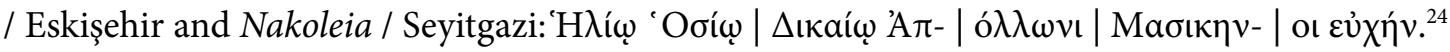

The latter document is quite complex. Its first editors have identified the three male figures in the relief on top of the stele with Helios, Apollo and Hosios-Dikaios, while accepting the traditional view that the Masikenoi hailed from an unlocated, but nearby village ${ }^{\star} M a s i k a{ }^{25}$ As I shall try to show elsewhere, this interpretation is problematic, not only because the visual and textual representation of the divinities would be incompatible, but also since the Lydian concept of the unity of Hosios (kai) Dikaios cannot simply be surmised in Phrygia without compelling indicators. Moreover, the gestures of the three figures are those of praying and sacrificing men. Therefore their divine attributes do not make them gods, but rather partakers in the divine nature as mystai. ${ }^{26}$ Two further pieces of evidence confirm that the Masikenoi were indeed members of a Dionysiac asso-

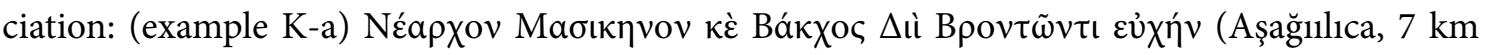

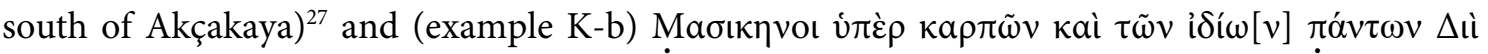

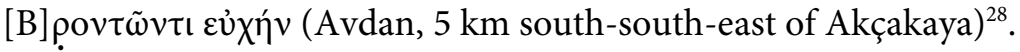

${ }^{22}$ Cf. P. Hamon in BE 2012, 408; Avram 2016b, 100.

${ }^{23}$ Zgusta 1984, § 772, with MAMA V 124 f.; cf. Frei 1988, 10-15; Akyürek Şahin 2004, 140; Avram 2016b, 96, 99 f. (quoting six inscriptions).

${ }^{24}$ 'To Helios, Hosios, Dikaios, Apollo the Masikenoi (have erected this stele, fulfilling their) vow.' (my translation).

${ }^{25}$ See Zgusta 1984, § 785; cf. Chiai 2009, 76; SEG 63, 1225.

${ }^{26}$ The first figure (embodying Helios Hosios?) holding his chest / heart with his right hand may be confessing, the second (embodying Dikaios Apollo? - his identification with Apollo is also doubted by T. Corsten in SEG 63, 2013, 1225) is about to sacrifice an animal with a labrys; the third (bearded), who raises his arms in the typical prayer gesture is invoking the gods. On hands or arms, see comparative evidence in

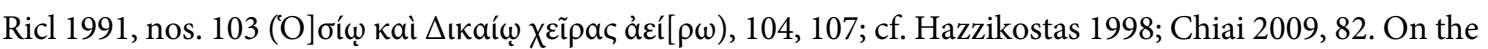
nimbus of mystai, see Keyßner 1936, esp. 595-597; cf. Weidle 1971/94; Willers 2006 with further references. On the iconography of the gods, also see the references above, in 8.

${ }^{27}$ Haspels 1971, vol. 1, 351 no. 137, with photo in vol. 2, ill. 636, on which the inscription is readable as

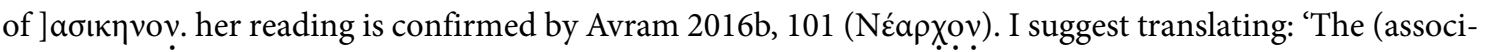
ation) Masikenon of Nearchos (or: of the Nearchoi?) and Bakchos (on whom see below, under example P) (erected this) to Zeus Bronton (in fulfilment of a) vow.' Aşağıllıca is mapped as (Sanctuary of) Zeus Bronton 2 in Talbert 2000, 62, D2, but the information is not compatible with Google Maps. For a useful map, see, e.g., Avram 2016b, 95 f. with fig. 3 (including Ilıca); cf. Ricl 1991, 51-53 (very useful, but without Aşağıllıca).

${ }^{28}$ See MAMA V no. 126 = Avram 2016b, 100 (with further references). I suggest translating it as follows: 'The Maskenoi (have dedicated this) for (the prosperity of) their crops and for (the well-being of) all their own (people / kin) to Zeus Bronton (in fulfilment of their) vow.' Avdan is mapped as (Sanctuary of) Zeus Bronton 1 in Talbert 2000, 62, E2. Avdan and Aşağıllıca are separate by a northern foothill of the Türkmen Dağları, on and around which several minor and perhaps even (for rural standards) major sanctuaries were located; see Haspels 1971, vol. 1, 164 and vol. 2, ill. 250-254; Ricl 1992a, 89; Avram 2016b, 95 f. 


\section{Five Dedications to Hosios kai Dikaios in the Mihalıççı District}

We can now turn to the new evidence from the Mihalıççı District. I begin with two inscribed limestone altars set up by the imperial slave Chryseros:

L (figs. 1-2) = Güney 2018a, no. 2, from Oğuz Pınarı on the road from Kayı (itself the first village on the road from Mihalıççı to Alpu in its west) to Aydınlar in its north, now in Kayı. The stone is inscribed at the top and at the bottom, with a large free space in-between:

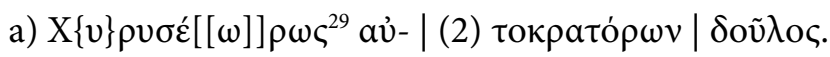

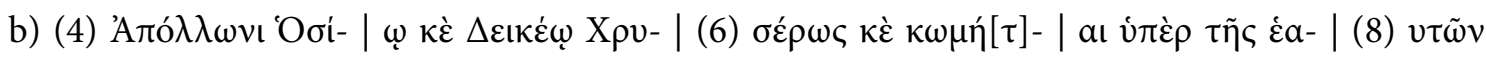

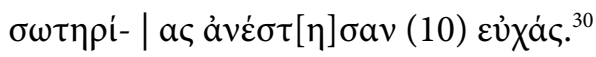

'Chryseros, slave of (the) emperors.'

'To Apollo, Hosios and Dikaios Chryseros and (the) villagers have erected (this altar) for their own (well-being) (in fulfilment of their) vows.'

M (fig. 3) = Güney 2018a, no. 3, also found in Oğuz Pınarı and now kept in Kayı:

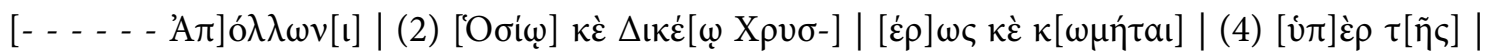
$\kappa \omega ́[\mu \eta \varsigma]|(6)[\dot{\alpha}] v \dot{\varepsilon} \sigma[\tau \eta \sigma \alpha v]|[\varepsilon \dot{x} \chi] \dot{\alpha}[\varsigma]$.

'[...] to Apollo, [Hosios] and Dikaios [Chryser] os and (the) v[illagers] have [e]rec[ted] (this altar) for the (well-being of the) village (in fulfilment of their) [v]o[ws]. ${ }^{31}$

Chryseros' status as imperial slave reminds us of the nearby imperial estates, the Choria Considi$a n a$, as they are called in a dedication which a certain Eutyches had ordered to be inscribed. It was found in Yukarı İğde Ağaç in the Beylikova District, to the south of Mihalıççı. That inscription characterizes Eutyches as the oikonomos of two Sebastoi, and since the same place also provides an inscription honouring Marcus Aurelius and Commodus, the dedication of Eutyches is dated to AD 177-180. Güney plausibly relates Chryseros to the same imperial estate and cautions us not to posit the role of oikonomos for him. This is indeed not necessary, although Chryseros must have played the most prominent role in the village mentioned in the two inscriptions. If so, all of its inhabitants were of unfree status, with Chryseros being their leader. ${ }^{32}$

As far as chronology is concerned, Güney dates his dedication after that of Eutyches based on the letter shapes. But palaeography is no safe criterion, especially if the comparative evidence comes

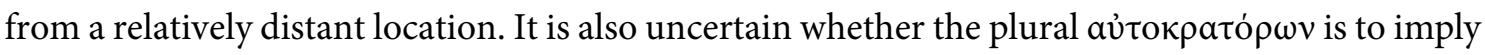

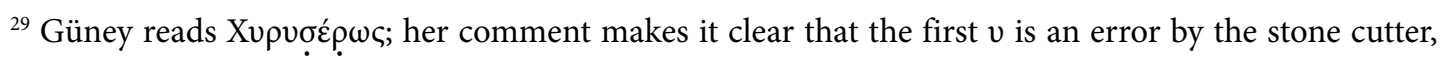
who got the name right in $11.5 \mathrm{f}$.; the $\sigma$, though weathered, is clearly visible on the photo; the second $\rho$ is written over an $\omega$, and then $\omega$ is repeated.

${ }^{30}$ Güney translates: 'Chryseros, slave of the emperor. Chryseros and the villagers performed a vow to Apollo, Hosios and Dikaios and set this up for their safety.'

${ }^{31}$ Güney translates: 'Chryseros? and the villagers? performed a vow to Apollo, Hosios and Dikaios and set this up for their village?'

${ }^{32}$ See Mitchell 1988 = RECAM II 34 and 36, with Güney 2016 on Eutyches. Güney, forthcoming suggests that there were probably seven villages when the Choria Considiana were established, together with the cult of Zeus Heptakomeiton.
} 
that Chryseros had served under more than one emperor successively or was currently serving under two co-ruling emperors. If the latter, these could be Marcus Aurelius and his brother Lucius Verus or his son Commodus, or Septimius Severus and Caracalla, if not Caracalla and his brother Geta. Hence, nearly any year in the later-2nd or early-3rd centuries is possible.

Of particular interest are the minor variations of the formulaic language. Chryseros and the villagers both appear as the dedicants, instead of the village(rs) alone, with Chryseros in the role of an executor (epimeletes). The first mention of Chryseros emphasizes his elevated status, but the

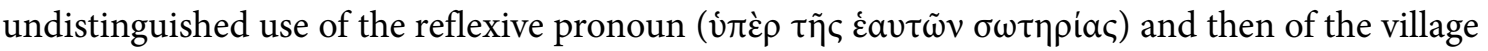
in connection with the beneficiaries makes it clear that Chryseros was one of them. Moreover, the fact that the village is not even named implies that the dedication was made on the territory of the village.

Another noteworthy variation of the standard formula is the plural of eủxác. Reference to a vow is normally made in the singular. The plural is certainly meaningful: either two vows made simultaneously by two different subjects (namely Chryseros and the villagers) are to be distinguished here or vows had been made in at least two different situations. Since there were (at least) two vows, there were (at least) two altars, located in the same place for the same divine triad of Apollo, Hosios and Dikaios. ${ }^{33}$

$\mathrm{N}$ (fig. 4) = Güney 2018a, no. 4 is from a damaged marble altar, also stored in Kayı, but having been brought in from Yukarı Dudaş, which is a few $\mathrm{km}$ further west on the road to Alpu. There is a relief of a horse-mounted deity underneath the inscription. It is broken off under the god's elbow (see Güney 2018a, 114, fig. 4). Güney leaves open whether it is Helios or Apollo. I am inclined to opt for Apollo, because there is no radiant crown visible and the longer name would also fit the lacuna better. The inscription reads:

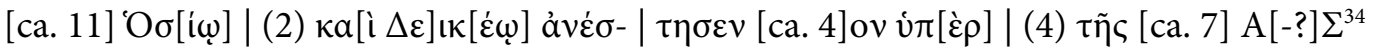

'N.N. has erected to [...] Hosios an[d D]ik[aios] (the Altar) for (the well-being) of [...]'.

One may assume that the initial lacuna in line 1 began with the name of the dedicant, unless [...]

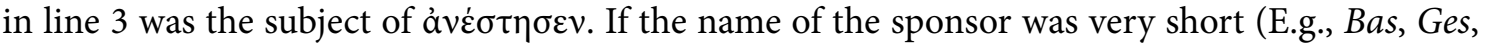
Mas), the list of the divine recipients of the dedication might even have included Apollo (as in $\mathrm{L}$ and $\mathrm{M}$ also from nearby Kayı) or potentially even Helios and Apollo (as in K from Akçakaya, though in a different order). In line 3, [ca. 4] ov could then have been the ending of the object. A tentative choice might be $[\beta \omega \mu]$ óv, consisting of three large letters. The two curves of B might even be seen on the photo, but if these are indeed traces of a $B$, then the lacuna was more likely to have

\footnotetext{
${ }^{33}$ This is more likely than assuming that there was a third, to mirror the divine triad. Otherwise, each altar would probably have been dedicated to only one god.

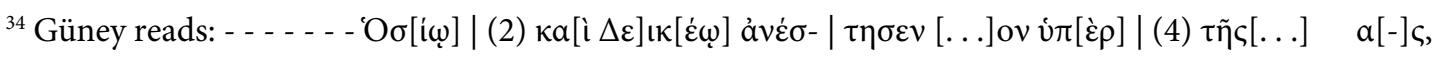
and translates: 'N. N. set this up (and performed a vow) to Hosios and Dikaios for their - - - -.' Güney's indications of what is left are unclear. While she seems to be implying that the first seven letters have been lost, I suggest that the initial lacuna was closer to 11 letters, given that $\mathrm{O} \Sigma$ are above $\mathrm{E} \Sigma$ of line 2. By the same count, the lacuna in line three before ON YП (the latter two stand below E $\Sigma$ ) comprised about 11-7 = 4 letters, while nearly everything is uncertain in line 4.
} 
4-5 rather than 3 letters. Add to this that the explicit mention of a sponsored altar in a dedicatory inscription requires the definite article. ${ }^{35}$

Hence, a better alternative is needed. ${ }^{36}$ We may let the first line begin, just as in $\mathrm{L}$ and $\mathrm{M}$, with

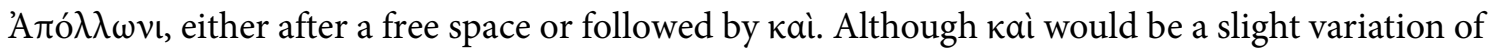
$\mathrm{L}$ and $\mathrm{M}$, the supplement would add up to exactly 11 letters. If this is accepted, then [ca. 4]ov

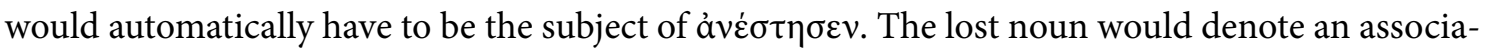
tion. $\mathrm{B}[\alpha \kappa \chi \tilde{l}]$ ov would be an excellent solution, starting with B, consisting of seven letters altogether and pointing to a Dionysiac thiasos, for which there is more evidence in the area, as indicated above (K-a, K-b) and explained further below $(\mathrm{O}, \mathrm{P}) .^{37}$

The reading å $v \varepsilon \dot{\varepsilon} \sigma-\mid \tau \eta \sigma \varepsilon v$ is plausible, although it requires us to leave the space of two letters free

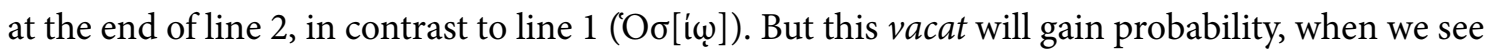
that it was repeated at the end of line 3, with the letters EP opening line 4. Most of this last line is in fact lost and Güney's $\tau \tilde{\eta} \varsigma$ is very uncertain, since it is hard to tell intentional strokes and damage apart. However, the upper bar of $\mathrm{E}$ and the vertical stroke of $\mathrm{P}$ are visible, and perhaps even the latter's (small) bow. The next letter is entirely uncertain, the subsequent one is $\mathrm{A}$ or $\Delta$, followed by $\mathrm{T}$, before the shade of $\mathrm{O}$ or $\Omega$ may be visible underneath $\mathrm{EN}$ (of line 3 ). If correct, this would imply smaller and thus more letters in line 4 , up to ca. 18 instead of $13 / 15$. Towards the end of the line, the upper left part of another $\mathrm{O}$ or $\Omega$ can be discerned, which we may complete to a genitive plural ending. The preceding letter is uncertain, but the one before that was either $\mathrm{A}$ or $\Delta$. In conclusion, I suggest the tentative reading:

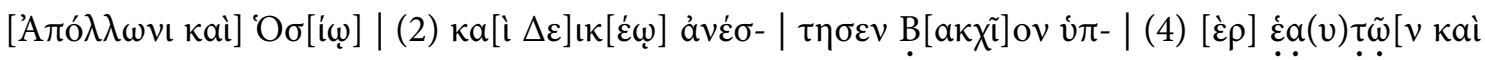
$\tau \tilde{\omega} v i] \delta[i] \omega[v]$.

'To [Apollo and] Hosios an[d D]ik[aios] has the Bakchion erected (the altar) for thems[elves and their o]wn.'

O (fig. 5) = Güney 2018a, no. 5 is a revised inscription of a marble altar, which C. G. J. Anderson had seen in Yukarı Dudaş (Anderson 1899, 80 no. 44 = Mitchell 1988, RECAM II 45 = Ricl 1991, no. 86), but which is now also in Kayı.

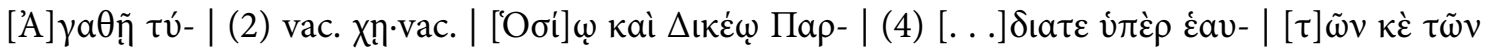

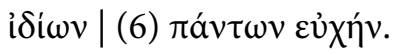

With good fortune! Par[---]diatai (erected this altar) to Hosios and Dikaios for (the well-being) of themselves and all their own (families), (fulfilling) a vow. ${ }^{38}$

Anderson, following Ramsey, understood the corrupt word in lines 2-3 as $\pi \alpha \rho[\alpha \gamma \omega] \delta$ iã $\tau$, i.e., 'wearers of the $\pi \alpha \rho \alpha \gamma \tilde{\omega} \delta \eta \varsigma^{\prime}$, which men bore as 'one of the insignia of office.. ${ }^{39}$ Güney is, however,

\footnotetext{
${ }^{35}$ I.Ankara I, p. 510 lists 17 examples, all with article. Also see above, G.

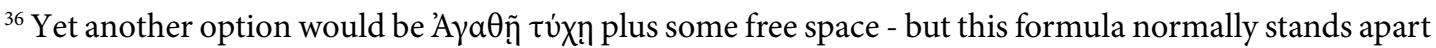
from the main text.

${ }^{37}$ See below, my discussion of $\mathrm{P}$, also addressing the abovementioned Masikenon from Aşağılıca.

${ }^{38}$ Güney translates: 'With good fortune! N. N. ... on behalf of themselves and their whole family performed a vow to Hosios and Dikaios.'

${ }^{39}$ Anderson 1899, 80.
} 
inclined to follow Mitchell's suggestion that we have to do with an incomplete, otherwise unknown ethnic, and therefore holds back from a tentative completion of the name. ${ }^{40}$ What tips the balance against an ethnic interpretation is how the beneficiaries of the dedication are expressed: 'for (the well-being) of themselves and all their own (families)'. We should therefore add this inscription from Yukarı Dudaş to the potential evidence for associations among the dedicants to Hosios kai Dikaios.

I remain unsure as to the supplementation. Ramsey's and Anderson's reading $\Pi \alpha \rho[\alpha \gamma \omega] \delta$ iã $\alpha \_$is only a theoretical possibility; the term might then hypothetically denote men distinguished by certain insignia, although the same restored word might also evoke a ritual procession in which a sacred object was paraded ( $\pi \alpha \rho \alpha ́ \gamma \varepsilon \sigma \theta a \imath$ ). But the ending - $\delta$ เ $\tilde{\tau} \varepsilon$ cannot easily be explained as Greek. For this reason, I abstain from a supplementation, other than accepting, with all previous

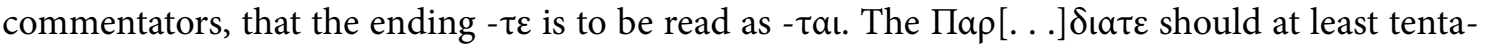
tively be added to our growing list of obscure names for associations in Phrygia. ${ }^{41}$ Many such groups in the area were devoted to Zeus Bronton ${ }^{42}$ or Dionysos, the latter of which may be alluded to in the reliefs on the monument from Yukarı Dudaş. ${ }^{43}$

P (fig. 6) = Güney 2018a, no. 1 is a marble altar that was reused in an ancient church building in Kayapınar, $2.2 \mathrm{~km}$ northeast of Otluk in the northeastern corner of the Mihalıççı District. Noteworthy is the (fragmentary) relief on top depicting Helios, holding four bridles attached to horses pulling his quadriga. Güney reads the inscription as follows:

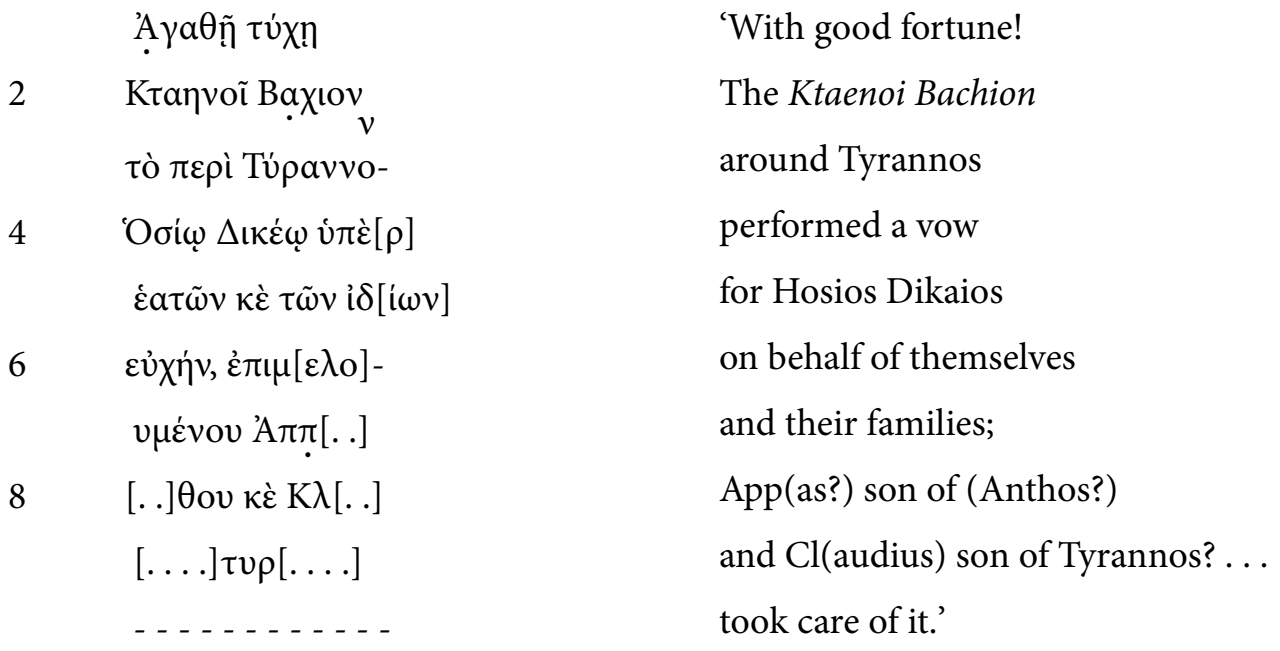

(Transl. Güney)

40 Thus also Ricl 1991, 39 f., no. 86.

${ }^{41}$ RECAM IV 25 exemplifies the risk of supplementing a hapax legomena, see appendix.

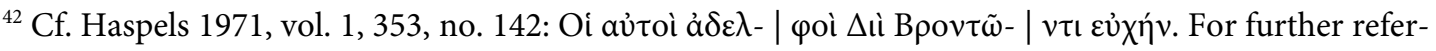
ences, see above, ns. 2, 7, $27 \mathrm{f}$.

${ }^{43}$ See (without this conclusion) the description of Güney 2018a, 106: 'figures clasping hands? and wearing chiton below the inscription, one of which holds the staff of justice; a bunch of grape with long stalk on the left side of the stone, a crater on the right depicted; fitted to the ground as used as pedestal for a flowerpot.' For similar objects, cf. the altar put up by the Mystai Koroseanoi Neobachchoi for Zeus Dionysios at Marlakkos/n: Haspels 1971, vol. 1, p. 354, no. 144; vol. 2, fig. 638. 


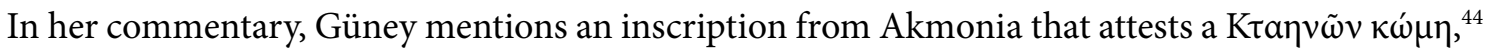
though she hesitates to identify those villagers with the Ktaenoi from Kayapınar, given a distance of about $240 \mathrm{~km}$. I agree with her hesitation, but not with her suggestion that there was a homonymous village near Kayapınar. ${ }^{45}$ Less clear is her understanding of Baxıv. She notes: 'Bachos as

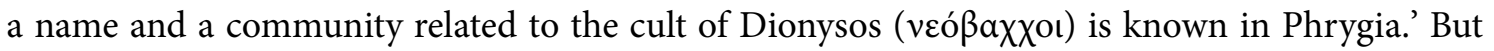
LGPN VC 84 (with MAMA V 168, from the countryside of Dorylaion) suggests reading the name from Dorylaion as Bá $\langle\kappa\rangle \chi 0 \varsigma$, i.e. the theonym in a secondary use as personal name. ${ }^{46} \mathrm{I}$ am thus inclined to correct this to read $\mathrm{B} \alpha\langle\kappa\rangle \chi \chi^{\circ} \mathrm{ov} .{ }^{47}$

Still, this does not yet account for the ending -ov, which renders the name neuter singular. ${ }^{48}$ The Neó $\beta a \chi \chi \circ$ o are putting us on a trail to solve the problem. They are attested in an inscription from

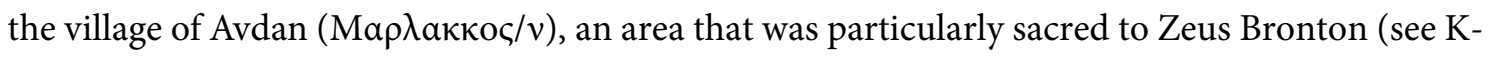
a, K-b), for whom various sanctuaries may have existed and over two dozen inscribed dedications have been found. ${ }^{49}$ Occasionally the god is also addressed as 'Zeus Dionysos', a conflation most likely due to the similar meaning of Bronton and Bakchios, ${ }^{50}$ besides the shared etymology of Zeus

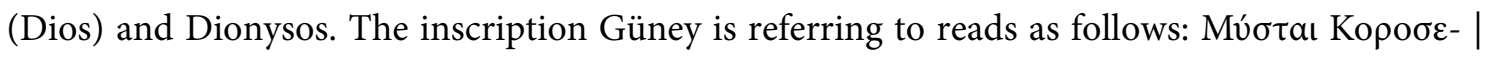

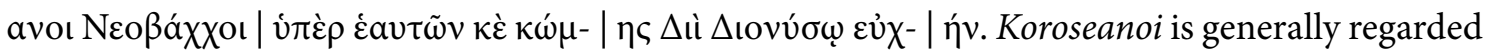
as an ethnic, ${ }^{51}$ and in view of the attestation of Korosokometai in Muratlar Köyü near Kotyaion / Kütahya, this would indeed be a plausible assumption. Akyürek Şahin hesitates from connecting the two names because of the distance to Avdan, but ultimately concludes that the home of the Korosokometai is likely to be found near Muratlar, where the Mystai Koroseanoi have been attested. ${ }^{52}$

Without denying that both names are etymologically related, a more plausible explanation would be that the Koroseanoi present themselves as a particularly defined subgroup of a Bacchic association in Marlakkos/ $n$ / Avdan. They appear to hail from or live in the same village, which is implied by the unspecified mention of $\kappa \omega \dot{\mu \eta} \varsigma$ ('their village') as secondary beneficiary after themselves. We can thus infer that the Koroseanoi were an association (whose adherents were not necessarily

\footnotetext{
${ }^{44}$ Cf. Zgusta 1984, §632a.

${ }^{45}$ She is now inclined to accept Klaenoi as a cult collegium (email, 2 Feb. 2020).

${ }^{46}$ Cf. Coşkun 2011 on theophoric personal names.

47 The letter(s) between $\mathrm{B}$ and $\mathrm{X}$ are difficult to read; most clearly visible is $\mathrm{A}$ or $\Lambda$, which might be preceded or followed by I, but these vertical strokes touch the subsequent letters, which otherwise only happens where the stone cutter intended a ligature. The strokes therefore appear to be unintended damage.

${ }^{48}$ I was initially inclined to read omega instead of omicron, to overcome the grammatical problem ('Klaenoi of the Bakchioi') and believed to find support for that in what seemed to be the two bottom hastae in the photo published by Güney. But the higher-resolution photos she kindly sent me confirm omicron.

${ }^{49}$ See above, ns. 2, 7, $27 \mathrm{f}$.

${ }^{50}$ Both epithets allude to the noisiness of the ecstatic cult rites, as does Bromios, the epithet of Dionysos known from his mystery cult in Smyrna: I.Smyrna 728; cf. Harland 2013, 58.

${ }^{51}$ E.g., cf. Haspels 1971, vol. 1, 354, no. 144; Zgusta 1984, § 588.

${ }^{52}$ Akyürek Şahin 2004, 140. Ricl 2008, no. 21 does not draw a connection with the inscription from Avdan, while Güney 2018a does not refer to the inscription from Muratlar Köyü; both leave the home location of the respective group open. Avram 2016b, 98 locates the Koroseanoi near Avdan, without specification.
} 
all designated mystai) and that they were living in Marlakkos/n. If this is the case, then these Koroseano $i$ have to be distiguished from the Korosokometai in Muratlar. At any rate, the dedication of the latter was likely made outside their own village territory, for otherwise they would barely have used a form of an ethnic that emphatically identifies them as villagers through the ending $\kappa \omega \mu$ íta. It is at least possible that they wanted to avoid being confused with a similarly named association. The inscription from Avdan thus attests that a cohort of new initiates to the Bacchic mysteries (Neoßá $\chi \chi 0 \mathrm{l})^{53}$ fulfilled their vow, expecting divine blessing for themselves and their village.

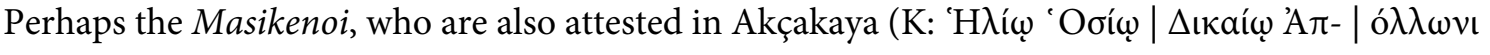

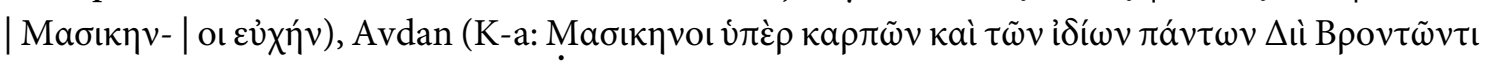

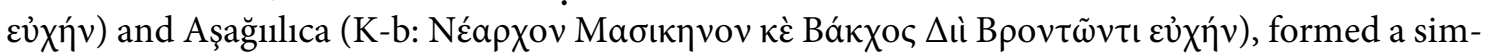
ilar association at the village level, just as the KHIOYEPHNOI $\mu v ́ \sigma \tau \alpha$, who are likewise attested as having made a dedication to Zeus Dionysos in Aşağıllıca. ${ }^{54}$

The inscription from Aşağıliıca (K-b) is further of interest due to the unique combination of dedicants: the Nearchon Masikenon and Bakchos. Is the latter the name of a high official within the cult organization (such as the leaders of the temple of Kybele in Pessinus are called Attis or Battakes), or is he the god Dionysos himself, meaning that part of the expenses had been covered from the treasury of (a sanctuary of) this god? Also remarkable is the juxtaposition of the nominative singular neuter (Nearchon Masikenon) with the nominative singular masculine (Bakchos). This seems to imply that the former denotes a unit within the Masikenoi community. If we can take Néa $\chi 0 v$ literally, then we might be looking at the 'New Leadership' level of the organization. However, a connection with an individual called Nearchos who held a prominent position in the association is likewise possible.

At all events, the inscription from Aşağıllıca (K-b) mentioning the Nearchon Masikenon together with Bakchos as well as the obscure neuter subject ending -ov attested in Kayl, most likely to be

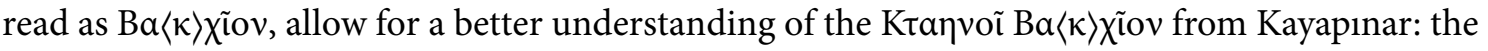

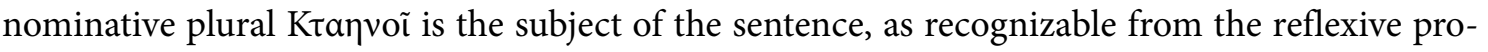
noun $\dot{\varepsilon} \alpha(v) \tau \tilde{\omega} v$, and $B \alpha\langle\kappa\rangle \chi \tilde{i} o v$, a generic term for a Dionysiac circle, serves as its apposition. The latter is complemented by a prepositional complement, tò $\pi \varepsilon \rho \grave{~ T u ́ p a v v o v . ~ T h i s ~ i m p l i e s ~ t h a t ~ t h e r e ~}$ were more Dionysiac associations in the area, possibly even more than one with the name Ktaenoi. Tyrannos may either have been the spiritual leader of this group or a perhaps a divine epithet for Dionysos (although it is also attested for Men and Zeus). ${ }^{55}$

Regarding the remainder of the inscription, it shows once more a twofold structure of the beneficiaries of the dedication: $\dot{v} \pi \dot{\varepsilon} \rho \dot{\varepsilon} \alpha(v) \tau \tilde{\omega} v \kappa \grave{\varepsilon} \tau \tilde{\omega} v \dot{i} \delta \dot{\delta} \omega v$. This is a plausible formulation from the point of view of the members of an association, but not for a collective of villagers.

Güney further proposes to restore the fragmentary names of the executors as App[as], son of [An]thos or [Pai]thos, and Kl[audios], son of Tyr[annos]. This reconstruction is possible, but it is

\footnotetext{
${ }^{53}$ On neoi and the likes, see below, n. 57.

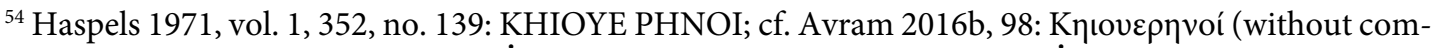
ment, but with more bibliography).

${ }^{55}$ It is attested for Zeus in Phrygia (MAMA V 12, cf. Chiai 2009, 87, 104) and for Men in Lydia (TAM V 536, cf. Mitchell 1993, vol. 1, 191; Harland 2013, 70; further IG II² 1365 f. = Harland 2014, no. 53).
} 
more likely that the two epimeletai were Roman citizens with a gentile name followed by a cognomen. Such an elevated social status would be fitting for their prominent roles, and the stone leaves sufficient space for the one additional I in line 7 or rather for the $\mathrm{Y}$ in line 8. Klaudios Tyrannos or Tyrannios is barely identical with or the son of the Tyrannos mentioned above in line 3, who does not bear a gentile name. Otherwise, Klaudios Tyrann(i)os would likely have been mentioned before App[ios] [An?]thos. We should therefore once more conclude that Tyrannos in line 3 is a divine epithet, whereas Tyrann(i)os suitably serves as cognomen of one of the god's devotees.

Güney adds a dashed line at the bottom, to indicate that the inscription might have continued on the now-lost part of the stone. But she has confirmed to me that no letter traces of another line are visible. Grammatically, the dedication appears to be complete, if the regular omission of the pred-

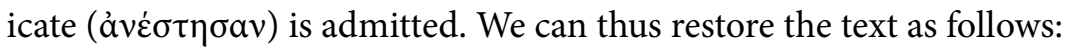

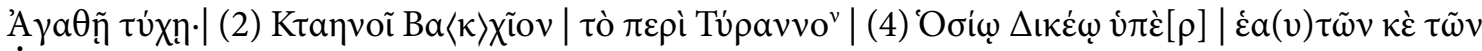

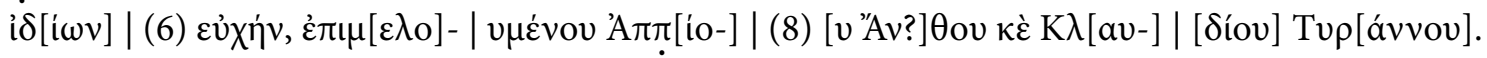

'With good fortune! The Ktaenoi, a Bacchic circle around Tyrannos, (fulfilled their) vow to Hosios Dikaios for (the well-being of) themselves and their own (families); App(as?), son of Anthos (?), and Klaudios, son of Tyrannos, took care of it.'

\section{Conclusions and Outlook}

My discussion of the five (mostly) new inscriptions recently published by Güney has started with the two dedications by Chryseros (Güney 2018a, nos. 2, 3 = L, M). Besides some minor improvements of the text, I have tried to enhance our understanding of the formulae and the implications of their variations, especially if the dedicants were (or included) a political community, such as a village. The inscriptions illustrate that dedications by a village community on its own territory do not need to use an ethnic or toponym. The use of either on home soil is the exception rather than the rule. ${ }^{56}$ Güney $(2018 \mathrm{a}$, no. $4=\mathrm{N})$ explains one of the three remaining inscriptions as a private dedication, while the other two seem to give us the ethnic of a public dedication (Güney 2018a, nos. $5,1=\mathrm{O}, \mathrm{P})$. Instead, I propose that all three inscriptions rather attest associations, a B $[\alpha \kappa \chi \tilde{l}] \mathrm{ov}$

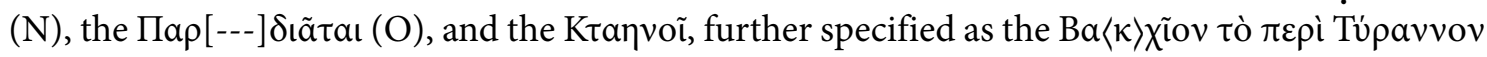
(P).

In the course of the argument, I also revisited some of the dedicatory inscriptions for Zeus Bronton or Zeus Dionysos in the sanctuary area on and around the Türkmen Mountains: while the intensive activity of associations is generally acknowledged for this region, I have questioned the standard practice of understanding - often obscure - names ending on - $\varepsilon a v o t$ or - $\eta$ vo regularly as top-

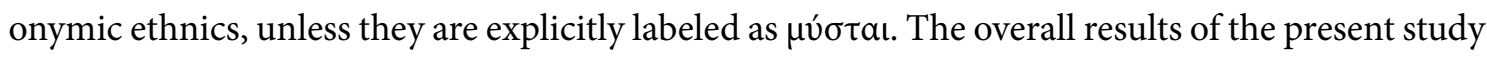
warrant further development of this criticism.

In her seminal studies of the cult of Hosios kai Dikaios from 1991/92, Ricl only acknowledges two instances of dedications by 'une association cultuelle', both from Yaylaba Köyü, the hotspot near the Türkmen Baba, the peak of the Türkmen Dağlar1. ${ }^{57}$ She contrasts them with nine dedications

\footnotetext{
${ }^{56}$ A clear exception is Marlakkos/n / Avdan, for which see the references above, n. 23, and below, n. 62.

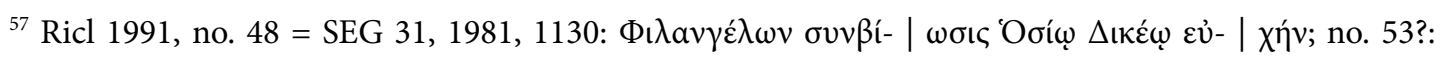
$[\Phi \iota \lambda \alpha v \gamma \varepsilon \dot{\lambda} \omega \nu v] \varepsilon \omega \tau \varepsilon \dot{\rho} \rho \omega v \mid[\sigma v v \beta i ́ \omega \sigma] ı \varsigma$. But the stone of no. 48 in fact reads $\Phi ı \lambda \alpha \mathrm{N} \Pi \varepsilon \dot{\lambda} \lambda \omega \nu$, as Malay 2005
} 
(also all from Phrygia) 'élevé soit par l'ensemble d'une communauté villageoise, soit par des particuliers pour la prospérité de leur village. ${ }^{58}$ In her update from 2008, Ricl points to only one new public dedication, that of the Kommenoi in Mysia (no. 37 = J). But from her catalogue, we certainly have to add the dedications by the Korosokometai attested in Muratlar (no. $21=\mathrm{H}$ ), the Koniskoumenon demos known from Lagina (no. $30=\mathrm{I}$ ), and also the Masikenoi attested on the monument from Akçakaya (no. $20=\mathrm{K}$ ), at least as long as we accept the prevailing views on them. To be consistent with Ricl's broad definition, we should moreover consider the mention of the patris among the beneficiaries in a private dedication from Doğanlar (no. $24=\mathrm{G}$ ). Finally, four of the five inscriptions adduced by Güney have to be counted in, although the dedication from Yukarı Dudaş first published by Anderson already forms part of Ricl's corpus (L, M, O = Ricl 1991, no. 86, P). Accordingly, current scholarship acknowledges up to 17 dedications to Hosios kai Dikaios involving a village.

We should, however, exclude from this count a highly fragmentary inscription that cannot have any weight in the present study ${ }^{59}$ When it comes to the dedicants proper, we ought to detract, moreover, three cases in which the village is not in charge. Twice it is meant to benefit from the invoked divine protection: once in Kuyacak (between Dorylaion and Nakoleia), where the dedicants are concerned about their katoikia, ${ }^{60}$ and once in Doğanlar (no. $24=\mathrm{G}$, mentioning the patris). These two cases are, again, good examples to highlight that toponyms were not needed in inscriptions on one's own village territory. A third document comes from İnönü, in which the ethnic Sakleanoi does not credit the whole village with a dedication, but only tells us that the two stone masons Diomas and Eutyches hail from ${ }^{*}$ Sakle- ${ }^{61}$

has shown, also adducing a hitherto unpublished inscription from the Manisa Museum that records a dedication of the Neoi Philanpeloi to Meter Leto (AD 161/62). We are thus looking at a community of 'VineLovers', which Malay connects with viticulture in the area (Strab. Geogr. 13.4.11), without, however, pointing out that the association was of a cultic nature: 'They describe themselves as véol, and it is not clear whether this adjective was employed to make a distinction between two rival associations of vine-lovers or points to a new organization replacing the older.' Malay's new reading is accepted by Ricl 2008, 566 (without further comment) and together with his interpretation also by Harland 2014, 143-145. But I suggest we take neoi and neoteroi as 'new' or 'recent initiates' of an association (also see above, ns. 27 and 53), and acknowledge moreover that the vine points to a Dionysiac thiasos. This would be in line with the rest of our evidence for Phrygian associations making dedications to Hosios kai Dikaios, see below, part IV, after n. 63 and with ns. $66 \mathrm{f}$.

${ }^{58}$ Ricl 1991, 85: nos. $25,29,33,37,40,80,81,86,96$. One might count as $8^{\text {th }}$ the dedication based on the decree of the city council and assembly of Nicopolis ad Istrum (JHS 45, 1925, 96 = Ricl 1991, no. 110), but I confine my investigation to the rural areas, for which all of Ricl's examples are from the Phrygian lands, mostly in northwestern Galatia.

${ }^{59}$ Ricl 1991, 80 from Zemme = JHS 8, 1887, 513, no. 94.

${ }^{60}$ Ricl 1991, no. 33 = MAMA V 184.

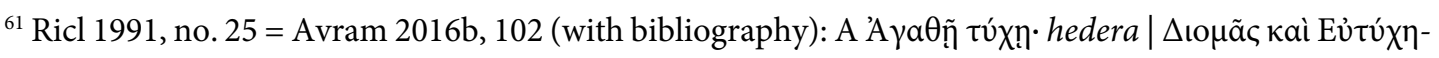

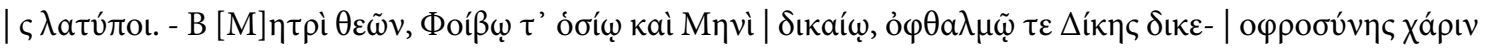

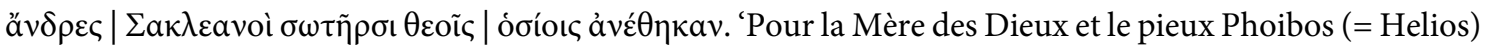
et le juste Men et l'oeil de la Iustitia, les hommes du village Sakle(-) ont consacré (ce monument) aux dieux sauveurs et pieux, par grace de justice.' (transl. Avram). 
Two other instances are spurious, because it is not the community that sponsors the dedication, but 'the best men of the village Marlakkos/ $n$ ' (Ricl 1991, no. 29) ${ }^{62}$ and 'those who pray among the Apokometai' (Ricl 1991, no. 37, from Nakoleia / Seyitgazi) ${ }^{63}$ Conspicuously, in both of these cases, the dedicants ask the gods 'for the salvation of all of their kin'. I next detract the cases that are better explained as evidence for Bacchic circles instead of ethnics: the Masikenoi from Akçakaya

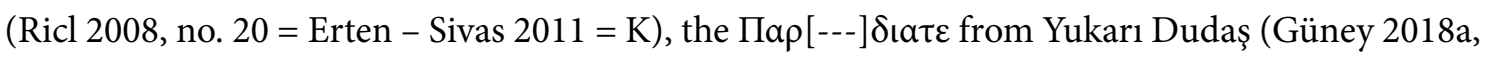

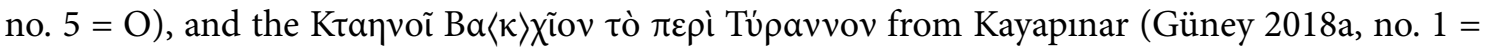
$\mathrm{P})$. Accordingly, the remaining total of dedications to Hosios kai Dikaios by entire villages is down from 17 to 8 . The number is reduced even further to 6 , if we also exclude dedicants for whom we have no solid basis to decide whether their name denotes a village community or an association. This pertains to the Pontanenoi attested in Akın south of Nakoleia as well as to the Kommenoi from near Hadrianeia. ${ }^{64}$

The limited evidence that does involve entire village communities approaching the divine couple falls into two groups. Three instances show a combination of an ethnic and generic term specifying that the proper name refers to an ethnic community: the Korosokometai from Muratlar near Kotyaion (Ricl 2008, no. $21=\mathrm{H}$ ), the Koniskoumenon demos from Lagina / Ilgin and the Alianon katoikia from Kurgll northwest of Çavdarhisar (Ricl 1991, no. 81 = REG 3, 1890, 51, no. 1). None

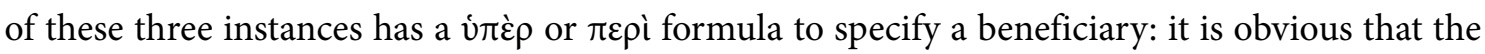
whole village is making a dedication for the well-being of the whole village. The second group does not even name the settlement type or its inhabitants: the dedicant Chryseros is twice followed by anonymous kometai ( $\mathrm{L}$ and $\mathrm{M}$ in Oğuz Pınarı near Kayı), where the purpose is once specified as $\dot{v} \pi \dot{\varepsilon} \rho \tau \tilde{\eta} \varsigma \dot{\varepsilon} \alpha v \tau \tilde{\omega} v \sigma \omega \tau \eta \operatorname{li}^{\prime} \varsigma$ and once as $[\dot{v} \pi] \dot{\varepsilon} \rho \tau[\tilde{\eta} \varsigma] \mid \kappa \dot{\omega}[\mu \eta \varsigma]$. Either expression is quite unspecific and in line with my proposal that a formula like $v \pi \dot{\varepsilon} \rho \tau \tilde{\omega} v$ i $\delta i \omega v$ would be unsuitable. The third example is from Karaağıl (Hadrianopolis) and mentions the anonymous demos, besides the priest Manes as its executor. ${ }^{65}$

At the same time, the number of ascertained associations is up from two to six. Since the dedica-

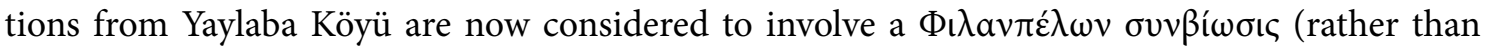
Philangeloi), ${ }^{66}$ they, too, conform with the description as Bacchic thiasoi, as with the other four

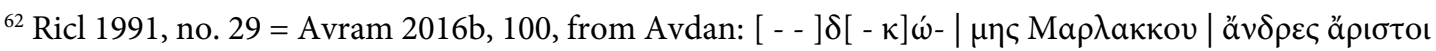

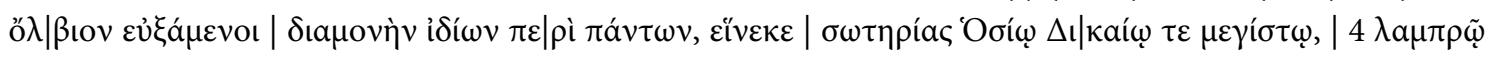

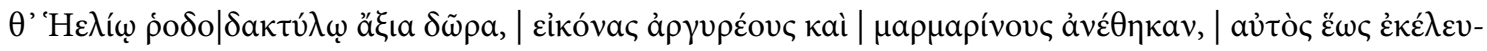

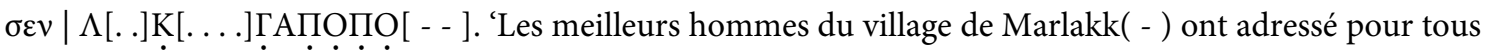
les leurs la prière de fortune permanente et ont consacré pour leur salut à Hosios et à Dikaios le très grand et au brillant Hélios aux doigts en forme de roses des présents prestigieux, (c'est-à-dire) des statues en argent et en marbre, comme il l'a commandé lui-même - -' (transl. Avram).

${ }^{63}$ SEG 28, 1978, 1177: 'А $\pi$ On the toponym, now see Avram 2016b, 97.

${ }^{64}$ Ricl 1991, no. $40=$ Haspels 1971, no. 152 and Ricl 2008, no. $37=$ J. Note that the name of the Kommenoi is clearly theophoric. It is certainly related to $\mathrm{Ma}$, the Anatolian Mother Goddesses, whose most prestigious sanctuaries were in Kommana Pontike and Kommana Hierapolis, but who also gave her name to Pisidian Komama; cf. Zgusta 1984, \$562 f.; Mutlu 2016.

${ }^{65}$ Ricl 1991, no. 96 = MAMA VII 132; cf. Frei 1988, 30 n. 64; Känel 1990, V.1, 543 no. 12.

${ }^{66}$ See above, n. 57. 
attested associations. The evidence for these associations is now as numerous as the proven cases of village communities making dedications to Hosios kai Dikaios. ${ }^{67}$ Two $(\mathrm{O}, \mathrm{P})$ or possibly three $(\mathrm{N})$ cases mention their kin generically among the beneficiaries, whereas the other half abstains from mentioning them. We should therefore avoid assuming that all unknown proper names with the suffix -enoi or -eanoi represent villagers. Based on the documentation and arguments I have presented here, we should rather expect that about half of the (likewise unspecific) dedications (not only) for Hosios kai Dikaios likely involve associations, or probably even more, since most cases in which a formula like $v \pi \dot{\varepsilon} \rho \tau \tilde{\omega} v i \delta i \omega v$ is used should tentatively be attributed to associations. It would seem to be a promising undertaking to revise our epigraphic and onomastic data in accordance with this hypothesis ${ }^{68}$ Moreover, we should also rethink the practice of identifying proper names as toponymic ethnics as soon as etymologically related topoynyms from near or even far are known. The same logic would require us to identify all proper names with plural endings derived from theonyms as denoting associations devoted to such deities. Apparently, such a practice would lead to a dilemma, as names derived from the goddess Ma might illustrate. ${ }^{69}$

I would like to conclude with some remarks on the organization of groups devoted to Hosios kai Dikaios. Not only is the total number of dedications by villages, associations or priests relatively low, if compared to the 185 documented cases. ${ }^{70}$ Our overall evidence also suggests that the cult of Hosios kai Dikaios was not normally administered by a designated priest or that a political community took regular care of sanctuaries for this divine pair. Nor is there evidence that such cults followed a calendar for sacrifices or celebrated specific holidays, or further that a thiasos was centred around Hosios kai Dikaios. The most outspoken exception is a monument from Kibyra attesting three priests who sponsored the construction of a 'temple for Herakles, his newly-born child Hosios and Dikaios and the Golden Virgin', with one of the priests even serving as 'temple warden' (neokoros). This was obviously a new and highly imaginative creation. ${ }^{71}$

For the rest, nothing seems to deserve the classification of cult organization, at least if that implies established institutions with funds belonging to the gods and personnel dedicated to their regular service. Offerings and prayers were of an irregular nature, mostly following private and only occasionally public initiatives. In the face of this lack of an established organization, the strong body of extant evidence for the Phrygians' devotion to Hosios kai Dikaios is all the more impressive. ${ }^{72}$ Given the appeal of these deities especially among the lower classes, we should not underestimate the importance of forming associations. Such associations offered the lower social strata more than

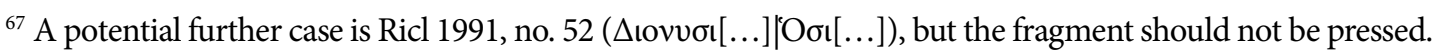

${ }^{68}$ Thus esp. Zgusta 1984; cf. Mitchell, RECAM II; Frei 1988.

${ }^{69}$ See my considerations on Kommenoi above, n. 64.

${ }^{70}$ Note that the three categories are not mutually exclusive. See, e.g., the case of the priest Manes acting on behalf of his demos (above, n. 66) or consider that mystery cults were not rarely sponsored publicly (cf. Harland 2014, 183-185).

${ }^{71}$ Ricl 2008, no. 41 = Corsten - Ricl 2012. - Another possible exception might be the monument from Akçakaya (K), for which I claim a mystery ritual involving Hosios kai Dikaios; at the same time, the Masikenoi rather appear as a Bacchic thiasos, see above.

${ }^{72}$ See Ricl 1992a, 88-90 and 2008, 566 on our very limited understanding of the cult organization, though she misleadingly conveys the impression that the priests were those of the cult of Hosios kai Dikaios, for which there is no evidence. On the priests and priestesses, also see above, with n. 11. 
simply a setting in which to pray to the gods who ostensibly had the power to bring justice and salvation; they offered a context in which to contribute substantial offerings to these deities and to fall under the umbrella of their protection. ${ }^{73}$

\section{Appendix: A Votive Offering to Dikaios by Another Thiasos in Konya (RECAM IV 25)?}

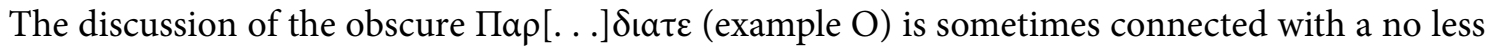
problematic inscription from the Konya Museum, for which many alternative readings have been

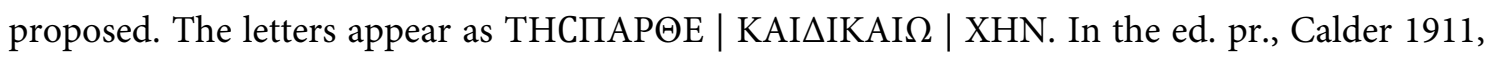
192-194, no. L (cf. SEG 6, 1932, 409) transcribed line 2 as KAГАIKAI $\Omega$ and read $\Gamma \tilde{\eta} \varsigma \pi \alpha \rho \theta \varepsilon-\mid \kappa \alpha$

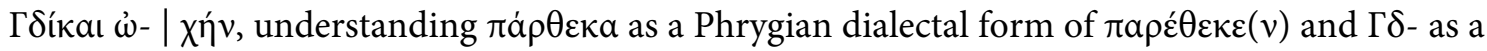
local variant for $\Delta$. Ricl 1991, no. 99 remained uncommitted between this and other readings, but accepted the dedication as one directed to Dikaios without Hosios (see above, n. 4).

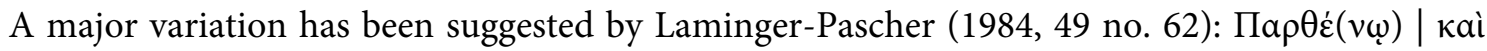
$\Delta$ เкaí $\omega$, whereby the Virgin is identified with Artemis. McLean $(2002=$ RECAM IV 25, with

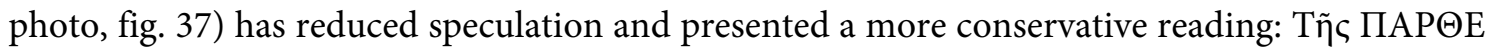
$\mid$ КАГ $\Delta$ เкаí $\omega \mid\langle\varepsilon \dot{v}\rangle \chi \eta \dot{v} v$. He is certainly right to point out that the veneration of Artemis as Virgin would be very unsual in Asia Minor. There was likewise no need to abbreviate the divine name or title, since the stone offers sufficient free space. But McLean too rashly rejects I instead of $\Gamma$ before $\Delta$. His choice would require us to accept that the horizontal bar of $\Gamma$ touched the $\Delta$ (as Calder saw it and for which he offered a questionable morphological explanation), although this would be inconsistent with the remainder of the inscription, which avoids ligatures of any kind.

None of the previous approaches has yielded a satisfactory reading so far, and this is perhaps because of the premise that the text is largely complete, with only few letters lost or abbreviated. I wonder, however, if there is not a better solution, even if it is admittedly hypothetical. To me, it seems that the stone cutter, who obviously did not understand Greek, was working from a note sheet whose left half had been lost. This view is not only supported by the difficult ending of line 1 and beginning of line 2, but also by the blank before XHN, which is conspicuously centered in line 3. Accordingly, the intended text might well have been quite unspectacular, e.g., ['Ovๆбik-

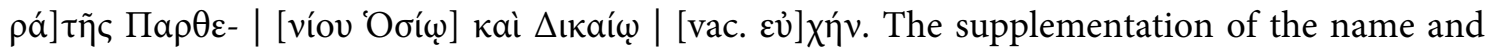
patronymic of the dedicant is just a random example, but the assumption that the votive offering had been for Hosios and Dikaios together is very likely.

${ }^{73}$ See Ricl 1992a, 87 and 2008, 565 f. on the (low) social strata of the dedicants. Harland 2013, 19-23 is of course right to caution against the view that members of any associations were typically poor; while he sees a preponderance of the middle classes, he concludes: 'Some [associations] could be more homogeneous, others more heterogeneous, in terms of the social standing and gender of group members.' A good example for an association's potential of levelling out social difference it the 'constitution' of a Dionysiac cult in Lydian Philadelphia, see SIG 985 = TAM V 1539 = Harland 2014, 178-193, no. 117, mentioning free and slaves side by side. 


\section{Bibliography}

Akyürek Şahin 2004

Anderson 1899

Ascough - Harland Kloppenborg 2012

Avram 2016a

Avram 2016b

Calder 1911

Chiai 2008

Chiai 2009

Corsten - Ricl 2012

Coşkun 2011

Erten - Sivas 2011

Erten 2018

Frei 1988

Gökalp Özdil 2016

Güney 2016

Güney 2018a
N. E. Akyürek Şahin, Neue Weihungen für Hosios kai Dikaios, Gephyra 1, 2004, 135-148.

J. C. G. Anderson, Exploration in Galatia Cis Halym, JHS 19, 1899, $52-134$.

R. S. Ascough - P. A. Harland - J. S. Kloppenborg, Associatians in the Greco-Roman World. A Sourcebook, Waco TX, 2012.

A. Avram, Two Phrygian Gods between Phrygia and Dacia, Colloquium Anatolicum 15, 2016, 71-83.

A. Avram, Propriétaires et citoyens à Dorylaion: enquête sur les citoyens romains et les villages sur le territoire, in: F. Lerouxel - A.-V. Pont (eds.), Propriétaires et citoyens dans l'Orient romain, Bordeaux 2016, 87-110.

W. M. Calder, Corpus Inscriptionum Neo-Phrygiorum, JHS 31, 1911, 161-215.

G. F. Chiai, Religiose Kommunikationsformen auf dem Land im kaiserzeitlichen Phrygien: Der Beitrag der Epigraphik, in: R. Häussler (ed.), Romanisation et épigraphie. Études interdisciplinaires sur l'acculturation et l'identité dans l'Empire romain (Archéologie et histoire romaine 17), Montagnac 2008, 351-374.

G. F. Chiai, Allmächtige Götter und fromme Menschen im ländlichen Kleinasien der Kaiserzeit, Millenium-Jahrbuch, 2009, 61-106.

T. Corsten - M. Ricl, A Dedication to Heracles, Hosios and Dikaos and Chrysea Parthenos from the Kibyratis, Gephyra 9, 2012, 143152.

A. Coşkun, Theophore Personennamen in Westkleinasien. Neue Überlegungen auf der Grundlage des Lexicon of Greek Personal Names, Vol. V.A: Pontus to Ionia (2010), EA 44, 2011, 153-162.

E. Erten - H. Sivas, Eine neue Weihung aus Phrygien, EA 44, 2011, $185-196$.

E. Erten, Dorylaion'dan Yeni Bir Hosios kai Dikaios Adağı ve Atlı Tanrı Üzerine Bazı Düşünceler, Phaselis 4, 2018, 199-217.

P. Frei, Phrygische Toponyme, EA 11, 1988, 9-34.

N. Gökalp Özdil, Antalya Müzesi'nden Yeni Adak Yazıtları, Phaselis 2, 2016, 245-258.

H. Güney, New Inscriptions from the Choria Considiana: Çalçak Roman Necropolis, AS 66, 2016, 125-139.

H. Güney, New Inscriptions from Northeast Phrygia: The Cult of Hosios and Dikaios, Gephyra 15, 2018, 101-117. 
Güney 2018b

Güney 2018c

Güney 2018d

Güney 2019a

Güney 2019b

Güney, forthcoming

Harland 2013

Harland 2014

Haspels 1971

Hazzikostas 1998

Känel 1990

Keyßner 1936

Laminger-Pascher 1984

LGPN VC

Lochmann 2003

Malay 2005

McLean 2002

Mitchell 1988
H. Güney, Ancient Quarries and Stonemasonry in Northern Choria Considiana, in: D. Matetić Poljak - K. Marasović (eds.), Proceedings of the XI ASMOSIA Conference (Split 2015), Split 2018.

H. Güney, New Epigraphic Documents from Northeast Phrygia, Philia 4, 2018, 55-66.

H. Güney, New Inscriptions from Northeast Phrygia, EA 51, 2018, 167-183.

H. Güney, The Sanctuary of Zeus Sarnendenos and the Cult of Zeus in Northeastern Phrygia, AS 69, 2019, 155-174.

H. Güney, A New Dedication to Potamos from Parsibey in Northeast Phrygia, Philia 5, 2019, 41-44.

H. Güney, The Imperial Estate Choria Considiana and "Zeus of the Seven Villages" in North-West Galatia, in: A. Coşkun (ed.), Galatian Victories and Other Studies into the Agency and Identity of the Galatians in the Hellenistic and Early-Roman Periods, forthcoming.

P. Harland, Associations, Synagogues, and Congregations. Claiming a Place in Ancient Mediterranean Society. $2^{\text {nd }}$ rev. ed. with links to inscriptions, Kitchener ON, 2013.

P. Harland, Greco-Roman Associations: Texts, Translations, and Commentary. Vol. 2: North Coast of the Black Sea, Asia Minor, Berlin-Boston 2014.

C. H. E. Haspels, The Highlands of Phrygia. Sites and Monuments, 2 vols, Princeton NJ, 1971.

D. Hazzikostas, Arms Raised, in: H. E. Roberts (ed.), Encyclopedia of Comparative Iconography. Themes Depicted in Works of Art, Chicago 1998, 51-58.

R. Känel, Hosios kai Dikaios, in: LIMC V.1, 1990, 542f. and V.2, $374 f$.

K. Keyßner, Nimbus, in: RE 17.1, 1936, 591-624.

G. Laminger-Pascher, Beiträge zu den griechischen Inschriften Lykaoniens, Vienna 1984.

J. -S. Balzat - R. W. V. Catling - É. Chiricat - T. Corsten (eds.), Lexicon of Greek Personal Names. Vol. V.C: Inland Asia Minor, Oxford 2018.

T. Lochmann, Studien zu kaiserzeitlichen Grab- und Votivreliefs aus Phrygien, Basel 2003.

H. Malay, Filanpeloi in Phrygia and Lydia, EA 38, 2005, 42-44.

B. H. McLean, Regional Epigraphic Catalogues of Asia Minor IV: Greek and Latin Inscriptions in the Konya Archaeological Museum (RECAM IV), London 2002.

S. Mitchell, Regional Epigraphic Catalogues of Asia Minor II: The 
Mitchell 1993

Mitchell 2017

Mutlu 2016

Petzl 1994

Petzl 2019a

Petzl 2019b

Piso 2018

Ricl 1991

Ricl 1992a

Ricl 1992b

Ricl 1994

Ricl 2008

Ricl 2017

Talbert 2000

Weidle 1971/94

Willers 2006

Zgusta 1984
Ankara District; The Inscriptions of North Galatia (RECAM II), Oxford 1988.

S. Mitchell, Anatolia. Land, Men, and Gods in Asia Minor. Vol. 1: The Celts in Anatolia and the Impact of Roman Rule; vol. 2: The Rise of the Church, Oxford 1993.

S. Mitchell, Two Galatian Cults in Dacia, Gephyra 14, 2017, 15-21.

S. Mutlu, Tanrıça Ma (Mã) ve Kappadokia Komana’sı, Phaselis 2, 2016, 311-322.

G. Petzl, Die Beichtinschriften Westkleinasiens, Bonn 1994.

G. Petzl, Die Beichtinschriften Westkleinasiens: Supplement, EA 52, 2019, 1-105.

G. Petzl, Sardis: Greek and Latin Inscriptions. Part II: Finds from 1958 to 2017, Cambridge MA, 2019.

I. Piso, Kleinasiatische Götter und Kolonisten in Dakien, Gephyra 16, 2018, 37-70.

M. Ricl, Hosios kai Dikaios. Première partie: Catalogue des inscriptions, EA 18, 1991, 1-70.

M. Ricl, Hosios kai Dikaios. Seconde partie: Analyse, EA 19, 1992, 71-103.

M. Ricl, Hosios kai Dikaios. Nouveaux monuments, EA 20, 1992, $95-$ 100 .

M. Ricl, Inscriptions votives inédites au musée d'Eskişehir, Živa antica 44, 1994, 157-174.

M. Ricl, Newly Published and Unpublished Inscriptions for Hosios and Dikaios and Their Contribution to the Study of the Cult, in: E. Winter (ed.), Vom Euphrat bis zum Bosporus Kleinasien in der Antike. FS für Elmar Schwertheim zum 65. Geburtstag, vol. II, Bonn 2008, 563-579.

M. Ricl, Cults of Phrygia Epiktetos in the Roman Imperial Period, EA 50, 2017, 133-148.

R. J. A. Talbert (ed.), Barrington Atlas of the Greek and Roman World, Princeton NJ, 2000.

W. Weidle, Nimbus, in: G. Bandmann et al. (eds.), Lexikon der christlichen Ikonographie, vol. 3, Rome 1971, repr. 1994, 323-332.

D. Willers, Nimbus [3], in: BNP 9, 2006, 763-766.

L. Zgusta, Kleinasiatische Ortsnamen, Heidelberg 1984. 


\section{Hosios kai Dikaios'a Adak Sunanlar İçindeki Dionysos Dernekleri Kuzeybatı Galatia Bölgesi’ndeki Mihallıççık’tan Yeni Yayımlanan Yazıtları Tekrar İncelemek Öz}

Mihalıçcık civarından dört yeni epigrafik buluntu, kutsal tanrı çifti Hosios ve Dikaios'a adak adayanlar arasında köyler ve derneklerin oynadığı rolü yeniden düşünmemiz için bizi teşvik etmektedir. Belgelerin dağılımına göre kült Phrygia-Epiktetos'un kuzey doğusunda ortaya çıkmış, orada yoğunlaşmış ve oradan tüm Batı Anadolu ve ötesine kadar yayılmıştır. M. Ricl (1991; 1992a; 2008) sayesinde önceden bilinen belgeleri gözden geçirip adak formülasyonlarının unsurlarını sınıflandırdıktan sonra, bu makalede H. Güney (2018a) tarafından ( 1 tanesi yeniden) yayımlanmış 5 yazıt için ufak düzeltmeler ve yorumlar sunulmaktadır. İmparator kölesi Khryseros’un köylü hemşehrileri ile birlikte bu tanrılara adak adadığı belgelenmiştir (no. 2-3); bununla birlikte diğer üçörnek

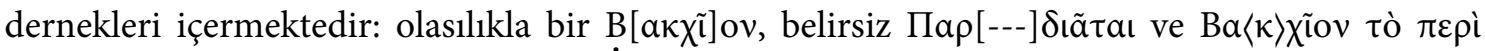

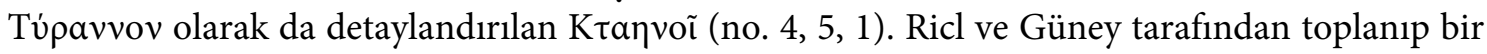
araya getirilen Hosios ve Dikaios adaklarının sayısı aşağı yukarı 185’e çıkmıştır. Onların fikrine göre 17 tanesi kırsal yerleşimlerden belgelenirken, yalnızca 2 tanesi derneklere aittir. Bu çalışma kesin olarak köylere atfedilecek yalnızca altı belgenin olduğunu ve bunun derneklere ilişkin belgelerle eşit olduğunu iddia etmektedir. Bu altı belgenin tamamı Dionysos kült derneğiyle özdeşleştirilmektedir.

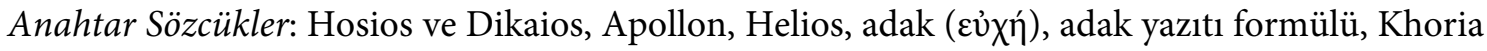
Konsidiana, Khryseros, Dionysos kült derneği, Bakkhion, Doğu Phrygia, Türkmen Dağları, Mihalıççı, Eskişehir, Kütahya.

\section{Dionysiac Associations among the Dedicants of Hosios kai Dikaios \\ Revisiting Recently Published Inscriptions from the Mihalıççı District in North-West Galatia \\ Abstract}

Four new epigraphic finds from the Mihalıççk District encourage us to reconsider the role that villages and associations played among those who made dedications to the divine pair Hosios kai Dikaios. According to the distribution of the evidence, the cult originated and remained concentrated on the north-east of Phrygia Epiktetos, but spread all over western Asia Minor and even beyond. After surveying the documents known previously especially thanks to M. Ricl (1991; 1992a; 2008) and classifying elements of the dedication formula, slightly improved readings and interpretations are offered for the five inscriptions (re-) published by H. Güney (2018a): twice, the imperial slave Chryseros is attested as fulfilling vows to the gods together with his fellow villagers (nos. 2, 3); three other instances, however, involve associations: perhaps a $\mathrm{B}[\alpha \kappa \chi \tilde{l}] \mathrm{ov}$, the

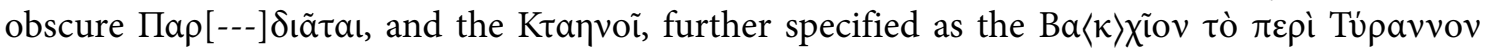
(nos. 4, 5, 1). The combined evidence catalogued by Ricl and Güney adds up to some 185 dedications to Hosios kai Dikaios, including, in their views, 17 cases that originated from village communities, compared to only two by associations. The present study argues instead that the ascertained evidence for villages is only six and that this is on par with the documentation of associations. All six of the latter can be identified as Dionysiac thiasoi.

Keywords: Hosios and Dikaios, Apollo, Helios, votive (eủxq́), dedication formula, Choria Considiana, Chryseros, Dionysiac Association, Bakchion, East Phrygia, Türkmen Mountains, Mihalıççık, Eskişehir, Kütahya. 

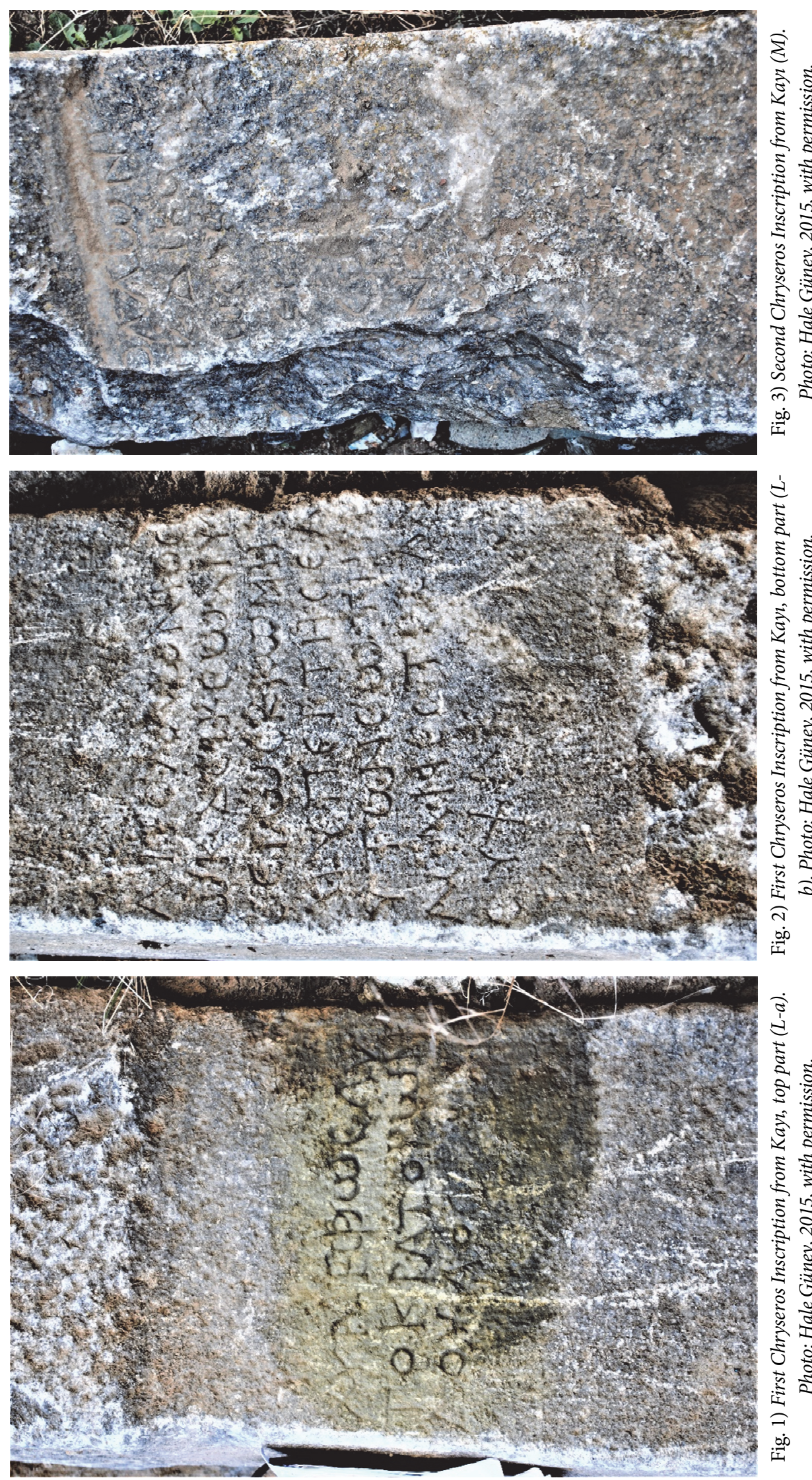


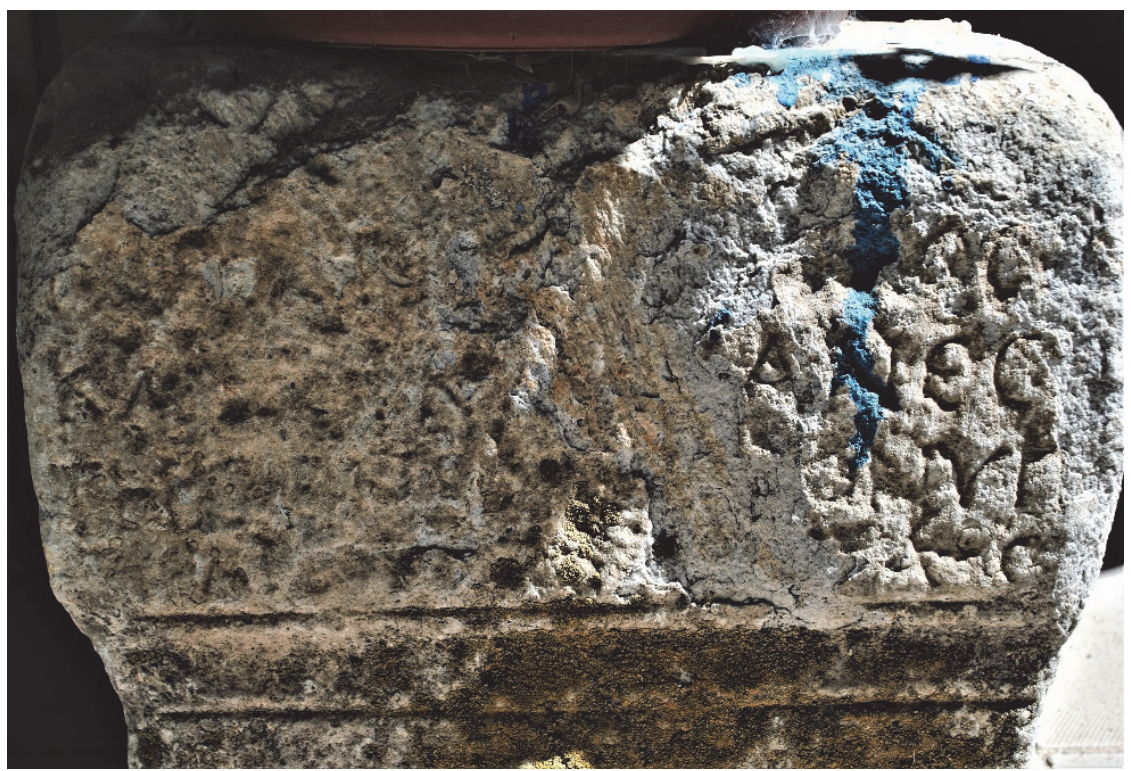

Fig. 4) New Dedication to Hosios kai Dikaios from Yukarı Dudaș (N). Photo: Hale Güney, 2015, with permission.

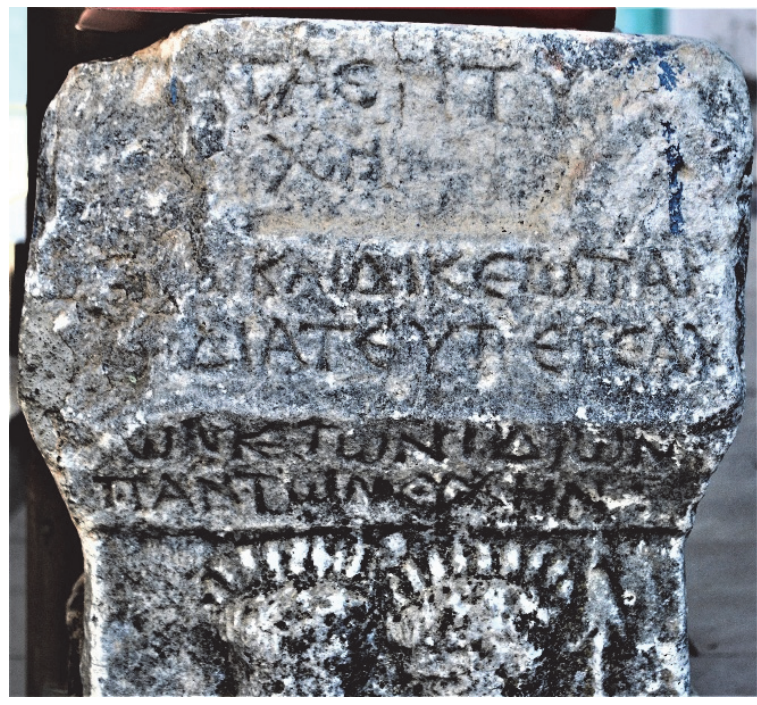

Fig. 5) Dedication to Hosios kai Dikaios first published by C. G. J. Anderson (O). Photo: Hale Güney, 2015, with permission.

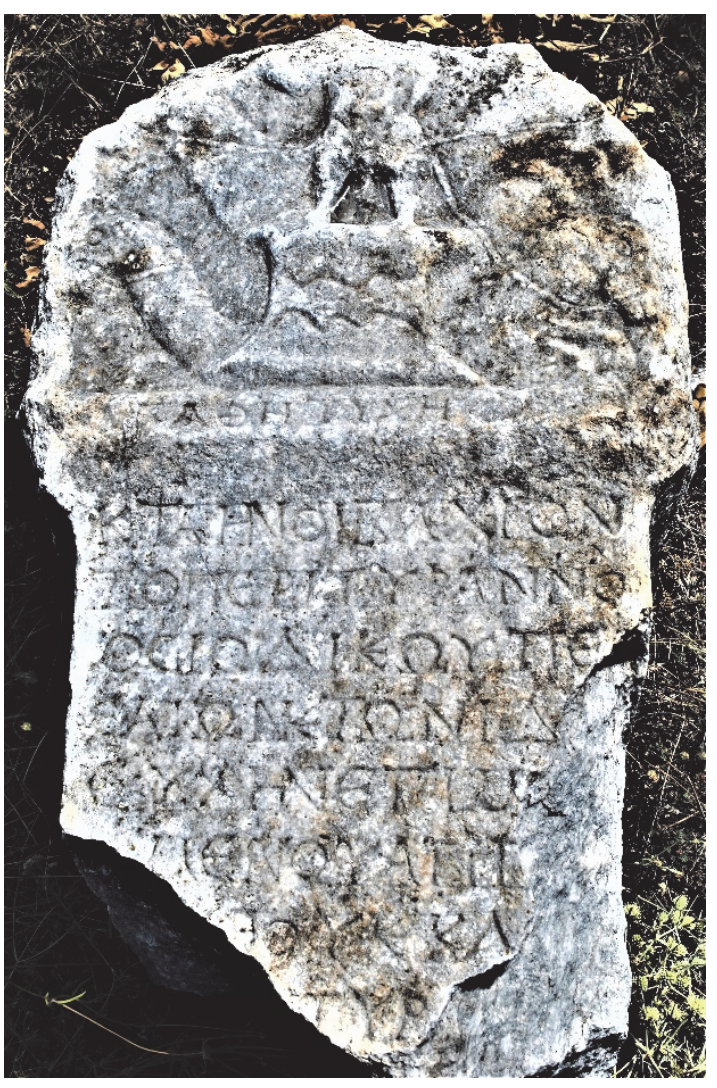

Fig. 6) Dedication by the Ktaenoi Ba $\langle k\rangle$ chion (P). Photo: Hale Güney, 2015, with permission. 